\title{
SPOŁECZNOŚĆ ŻYDOWSKA
}

\author{
Ewa Wiatr \\ Centrum Badań Żydowskich \\ Uniwersytet Łódzki
}

\section{Życie kulturalne Żydów w Lodzi w latach 1945-1950}

\section{Wprowadzenie}

Jak zwykło się powtarzać, Łódź w pierwszych latach po wojnie stała się nieformalną stolicą Polski. Tutaj osiedliły się urzędy centralne, do Łodzi, choć jak potem się okazało jedynie tranzytem, przyjeżdżali urzędnicy, literaci, aktorzy, naukowcy znajdując to, czego nie mogła im zapewnić zrujnowana Warszawa - puste mieszkania po wysiedlonych Niemcach. Łódź nie uległa w czasie wojny poważnym zniszczeniom. Nie nastapiła dewastacja zabudowań i infrastruktury, zachowały się archiwa i budynki użyteczności publicznej. Można powiedzieć, że najbardziej brakowało ludzi. Zmieniło się bowiem zupełnie oblicze narodowościowe miasta, które przestało być skupiskiem koegzystujących przed wojną trzech narodowości - Polaków, Żydów i Niemców. Likwidacja łódzkiego getta w sierpniu 1944 r. stała się praktycznie końcem żydowskiej Łodzi w przedwojennym obliczu. Polityka eksterminacyjna okupanta brutalnie rozprawiła się z inteligencją łódzka, przynajmniej tą jej częścią, które nie zbiegła we wrześniu 1939 r. na wschód. Ci którzy ocaleli, nie zawsze odpowiadali nowej władzy ze względu na poglądy polityczne i przedwojenną aktywność. Stąd też ogromny niedobór ludzi wykształconych do pracy w urzędach, a praktycznie, w pierwszym okresie - do pracy w wojsku i służbach bezpieczeństwa. Często trafiali tam ludzie zaczepiani na ulicy, a kryterium doboru, jak twierdzi Samuel Sandler, bywał żydowski wygląd: „żeby się jacyś volksdeutsche nie wkręcili do wojska, bo podobno próbowali. A Żyda nie trzeba było sprawdzać. Na pewno nie współpracował z Niemcami i nie był volksdeutschem" .

$\mathrm{Na}$ wizerunku i pamięci o Łodzi ciąży bliskość Warszawy. Nikt nie może zaprzeczyć, że w pierwszych latach po wojnie to tutaj toczyło się praktycznie życie kulturalne i polityczne Polski, niemniej bardzo często fakt ten jest przemilczany. Pobyt w Łodzi miał niestety charakter przejściowy, co najlepiej oddaje tytuł publikacji „Tranzytem przez Łódź”, zawierającej wspomnienia ludzi, którzy tu znaleźli wówczas dom i pracę. Łódź stała się poczekalnią na

\footnotetext{
1 „Gazeta Wyborcza”, 6 III 2010. Wywiad z Samuelem Sandlerem.
} 
czas odbudowy stolicy. Szczególnie jaskrawo widać to w przypadku społeczności żydowskiej, której najlepsze lata politycznej i kulturalnej autonomii przypadają właśnie na okres, gdy większość instytucji i osób w niej działających przebywała w Łodzi, będącym wówczas największym miejskim ośrodkiem zamieszkania Żydów. Celem niniejszego artykułu jest ukazanie odradzania się żydowskiego życia kulturalnego w Łodzi, przede wszystkim w jego nowoczesnym charakterze.

W powojennej rzeczywistości przed Żydami pojawiło się kilka dróg ułożenia sobie życia. Mogli trwać przy ideach syjonistycznych, zwłaszcza wobec coraz bardziej realnej możliwości odbudowy państwa Izrael, mogli pozostać w kraju, zarówno budując swoją przyszłość w oparciu o kulturową i religijną odrębność bądź też wybrać asymilację jako najwłaściwszą z dróg, zwłaszcza wobec składanych przez nowy ustrój obietnic budowy społeczeństwa bez podziałów na tle narodowościowym.

\section{Uwarunkowania społeczno-polityczne}

Ludność żydowska, a szacuje się, że ocalało około 10\% przedwojennej substancji etnicznej Żydów polskich ${ }^{2}$, jako jedyna spośród mniejszości narodowych, uzyskała możliwość powoływania patii narodowych i politycznych o charakterze narodowym. Największą popularnością cieszyły się partie syjonistyczne różnych orientacji, mniejsze poparcie miał Bund i żydowska Frakcja PPR, którą można uznać za jedyną sekcję etniczną partii komunistycznej w powojennej Polsce ${ }^{3}$. Przedstawiciele żydowskich partii politycznych skupiły się w powołanym w listopadzie 1944 r. w Lublinie Centralnym Komitecie Żydów w Polsce. Zadaniem Komitetu była koordynacja całego życia żydowskiego w Polsce.

Pierwsze lata po wojnie to okres toczenia się swoistej walki o rząd dusz wśród ludności żydowskiej, toczonej pomiędzy dwoma skrajnymi ugrupowaniami: z jednej strony kierujący się ideami internacjonalistycznymi i paradoksalnie, zachęcający do pozostania w kraju oraz nacjonaliści, dla których budowanie przyszłości możliwe było wyłącznie w Erec Izrael, a pobyt w Polsce był tylko okresem przejściowym. Wyznawane poglądy determinowały stosunek do kultury żydowskiej. Dla jednych ważne stało się odbudowywanie żydowskiego życia kulturalnego $\mathrm{w}$ wymiarze tradycyjnym, w kręgu języka jidysz, inni z kolei pragnęli tworzyć żydowski świat, przygotowany do zaszczepienia w przyszłym własnym kraju i wytrwale uczyli się w tym celu języka hebrajskiego. Istotną grupę stanowi Żydzi, którzy pragnęli zachować kulturową odrębność, ale nie zamykać się przed związkami z polskością. Ci ostatni wydawali się być najbliżej zapatrywaniom nowej władzy na problem żydowski, choć wraz z malejącą

${ }^{2}$ L. Olejnik, Polityka narodowościowa Polski w latach 1944-1960, Łódź 2003, s. 344.

${ }^{3}$ A. Grabski, Ksztaltowanie się pierwotnego programu żydowskich komunistów w Polsce po Holocauście, [w:] Studia z dziejów historii Żydów w Polsce po 1945 roku, pod red. G. Berenta, A. Grabskiego i A. Stankowskiego, Warszawa 2000, s. 67. 
autonomią Żydów w Polsce coraz większy nacisk kładziony był na całkowitą asymilację.

Warto również wspomnieć o wielu mieszkańcach Łodzi i Polski, którzy chcieli, aby problem żydowskiego pochodzenia przestał stanowić jakikolwiek wyznacznik pozycji społecznej. Byli wśród nich zarówno ci, którzy ufali, że w nowym ustroju będą mogli być obywatelami bez stygmatu narodowości oraz ci, którzy od dawna żyli już w kręgach kultury polskiej. Aktywność i jednych i drugich w tworzeniu podwalin nowego życia w Polsce była bardzo duża. Jak zauważył Artur Sandauer, w łódzkiej „Kuźnicy”, czyli w organie „wściekłych, czerwonych encyklopedystów" na 12 członków redakcji siedmiu było pochodzenia żydowskiego ${ }^{4}$. Byli to jednak twórcy, których celem nie było tworzenie w kręgach kultury żydowskiej. Nie jest też moim zamiarem tropienie w niniejszym artykule pisarzy, malarzy czy aktorów mieszkających po wojnie w Lodzi pochodzenia żydowskiego, skoro oni sami nie utożsamiali się z kulturą żydowską i nie dążyli do jej tworzenia.

Problemy z jakimi przyszło się borykać Żydom tuż po wojnie to przede wszystkim ubóstwo materialne, często brak jakichkolwiek dokumentów potwierdzających tożsamość o pamiątkach rodzinnych nie wspominając. Do tego dochodziła trauma po stracie rodziny, a przyjąć należy, że każdy kogoś stracił, oraz niepewność co do dalszego losu. Ludzie byli osamotnieni i najcześciej rozgoryczeni. Irena Hurwic-Nowakowska prowadząca badania socjologiczne wśród ocalałych Żydów scharakteryzowała ich jako „zbiorowisko do pewnego stopnia patologiczne, obarczone kompleksami, urazami, skłonne do zbiorowych psychoz"5. Taka postawa rodziła oczywiście tendencję do generalizowania i przypisywania antysemityzmu większości Polaków, a skutkiem tego była chęć jak najszybszego opuszczenia kraju, który stał się dla nich „wielkim cmentarzem". Na drugim biegunie znajdowali się sympatycy komunizmu i Bundu, mający nadzieję na zdecydowanie inne traktowanie w nowym układzie politycznym i pragnący tę nową rzeczywistość tworzyć, a zarazem odbudować życie żydowskie. Sytuację doskonale ilustruje krążąca wówczas anegdota żydowska:

Co robią dziś Żydzi w Polsce?

Jeden Żyd - daje ogłoszenie do prasy, że szuka krewnych.

Dwóch Żydów - zakłada zespół artystyczny i otwiera teatr.

Trzech Żydów - zakłada sobie partię.

Czterech Żydów - prowadzi Centralny Komitet.

Pięciu Żydów - zakłada kibuc.

Sześciu Żydów - wynajmuje na spółkę mieszkanie.

A pozostała garstka Żydów czeka na wizy. ${ }^{6}$

${ }^{4}$ A. Sandauer, O sytuacji pisarza polskiego pochodzenia żydowskiego $w$ Polsce $w X X w$., Warszawa 1982, s. 61.

${ }^{5}$ I. Hurwic-Nowakowska, op.cit., s. 46.

${ }^{6}$ M. Nudelman, Gelechter durch trern. Zamlung fun humoristisz-satirisze szafungen funem noch-milchomedikn lebn fun pojlisze jidn, Buenos Aires 1947 s. 19. Cyt. za J. Nalewajko-Kulikov, Obywatel Jidyszlandu. Rzecz o Żydowskich komunistach w Polsce, Warszawa 2009., s. 164. 
W Łodzi bardzo szybko pojawiły się żydowskie organizacje polityczne, $\mathrm{W}$ większości funkcjonujące już przed wojną. Jak wynika $\mathrm{z}$ pisma ${ }^{7}$ prezydenta miasta Łodzi do Ministerstwa Administracji Publicznej, do października 1945 r. wznowiły swoją działalność Żydowska Socjalistyczna Partia Robotnicza Poalej Syjon zjednoczona z C.S. (Ceire Syjon - Młodzi Syjonu), Hitachdut, Haszomer Hacair, Dror, Gordonia i Hapeel, które połączyły się w Obóz Pracującej Palestyny. Siedzibą wszystkich tych organizacji stały się lokale partii przy ul. Zachodniej 26, Wólczańskiej 1/15 i Wólczańskiej 1/18, a osobami odpowiedzialnymi przed władzami byli Hilary Sztrowajs, Lajb Szeftel i Cemach Rozencwajg. Oficjalnie powołany również został łódzki oddział Zjednoczenia Syjonistów Demokratów Ichud w Polsce, z siedzibą przy ul. Gdańskiej 44. W październiku 1945 r. do partii tej należało jedynie 198 osób.

Do życia powołano również Żydowskie Stronnictwo Demokratyczne, którego siedzibą stał się lokal Polskiego Stronnictwa Demokratycznego przy ul. Piotrkowskiej 78. Partia ta nie uzyskała jednak akceptacji władz i zaprzestała legalnej działalności.

Przed wszystkimi partiami i organizacjami politycznymi stało przede wszystkim zadanie zorganizowania przybywającym do Łodzi licznym rzeszom Żydów mieszkania, ubrania, wyżywienia i pracy. Większość przybywających, zarówno wyzwolonych z obozów jak i repatriantów czy ukrywających się w lasach, nie posiadała żadnego majątku. Sytuacja powracającej bądź przybywającej do Łodzi ludności żydowskiej wymusiła na tych organizacjach podjęcie szeroko zakrojonej akcji pomocy, zarówno finansowej czy materialnej jak i organizacyjnej. W materiałach przygotowywanych dla Sekcji Kontroli American Joint Distribution Comittee w maju 1946 r. Łódź jawi się jako siedziba centrali wszystkich znaczących instytucji i organizacji prowadzących domy dziecka, kuchnie społeczne czy kibuce, nawet jeśli ich oddziały funkcjonują na Dolnym Śląsku czy w Szczecinie.

W Łodzi działały kibuce młodzieżowych organizacji syjonistycznych, a więc Droru przy ul. Południowej 18 (obecnie ul. Rewolucji 1905 r. ), Haszomer Hacair przy ul. Kilińskiego 49, Gordonii przy ul. Wólczańskiej 43 i Poalej Syjon Lewicy im. Berdyczewa przy ul. Narutowicza 25. Organizacja Dror prowadziła również dom dziecka przy ul. Wólczańskiej 78. Funkcjonował również kibuc Ichudu przy ul. Zachodniej 20 oraz kibuce prowadzone przez Żydowskie Zrzeszenie Religijne dla repatriantów i zdemobilizowanych żołnierzy przy ul. Cegielnianej 26 (obecnie ul. Jaracza) i dla młodzieży przy ul. Południowej 20 (obecnie ul. Rewolucji 1905 r.) oraz żeński przy ul. Zachodniej 66 i męski przy ul. Nowomiejskiej 8. Warto zwrócić uwagę na adresy tych i innych organizacji żydowskich w Łodzi - były to najczęściej ulice zamieszkałe przed wojną przez zasymilowaną ludność żydowską. Według zestawienia datowanego na maj 1946 r., najliczniejsze były kibuce związane z organizacjami syjonistycznymi

\footnotetext{
${ }^{7}$ APŁ, Zarząd Miejski w Łodzi, Wydział Adm., sygn. 103. S. 8-10.
} 
(Dror - 205 osób, Haszomer Hacair - 150, pozostałe ok. 100). Liczny był również kibuc związany ze Zjednoczeniem Syjonistów Demokratów Ichud 150 osób. Przy kibucach organizowano warsztaty, najczęściej szewskie, stolarskie, krawieckie i ślusarskie. Starano się również wysyłać członków kibuców do pracy w przedsiębiorstwach, choć w przypadku kibuców religijnych problemem była praca w soboty. Kibuce utrzymywały się z pracy w warsztatach i przedsiębiorstwach oraz z dotacji od organizacji centralnych, które z kolei najczęściej otrzymywały środki z zagranicy (m.in. z Jointu). Większość członków kibuców stanowili repatrianci ${ }^{8}$. Możliwość zamieszkania w kibucach była $\mathrm{w}$ wielu przypadkach jedyną możliwością zorganizowania sobie podstaw egzystencji, zwłaszcza że w tzw. domach repatrianta można było zatrzymać się jedynie 5 dni, w dodatku najczęściej nie otrzymując wyżywienia. Dla żydowskiej młodzieży, najczęściej osieroconej i pozbawionej jakiegokolwiek majątku, kibuce stanowiły krok w kierunku uporządkowania swojego życia, zdobycia zawodu, pracy, nawiązania znajomości, które bardzo często przeradzały się w małżeństwa. Wiele osób z czasem opuszczała wspólne siedziby, zdobywając mieszkania w mieście bądź wyjeżdżając z Łodzi w poszukiwaniu pracy na Ziemie Odzyskane lub emigrując za granicę?.

Warto również wspomnieć o funkcjonującej od kwietnia 1946 r. przy ul. Franciszkańskiej 15 Bursie dla młodzieży. „Bursanci” stworzyli specyficzną społeczność, która utrzymywała ze sobą związki jeszcze wiele lat po wojnie, mimo rozproszenia mieszkańców praktycznie po całym świecie. W szczytowym okresie w Bursie przebywało około 150 osób, w sumie mieszkało prawdopodobnie ok. 200. Administracyjnie kierownictwo Bursy było w rękach PPR, i przeważała młodzież należąca do ZWM i ZAMP (po zjednoczeniu ZMP), to tam, jak wspomina Adam Broner, działały również grupy syjonistyczne i bundowskie, prowadząc gorące dyskusje polityczne w pokojach i świetlicy. Byli mieszkańcy Bursy wspominają spędzony w niej czas jako okres wyjątkowo intensywnego życia. Jak ujął to Adam Bonar: „Cechą charakterystyczną zachowania się bursantów była chęć zapomnienia tych koszmarów przez które przeszli. Entuzjastyczny poryw do nowego życia był instrumentem wykorzystywanym w tym celu. Bursanci podświadomie tworzyli i wykorzystywali intensywny tryb życia podejmując pracę zarobkową, naukę i nawet zabawę by tylko być zajętym i zapomnieć o tragedii przeszłości. Życie kulturalne w Bursie było bardzo intensywne. Występy artystyczne, deklamacje, śpiew, uroczyste akademie, wykonywane przez bursantów oraz huczne potańcówki przyciągały wielu gości z miasta. Bursa była unikalnym ośrodkiem kulturalnym dla młodzieży miasta" ${ }^{\prime \prime}$.

\footnotetext{
${ }^{8}$ IPN, BU 1208/155, cz 2, s. 482-485.

${ }^{9}$ Por. R. i E. Grynfeldowie, Gwizd życia, Łódź 2005.

${ }^{10}$ Korespondencja z A. Bronerem.
} 


\section{Aktywność kulturalna partii i organizacji żydowskich}

Jako najliczniej zamieszkałe przez Żydów miasto po wojnie, Łódź była widownią wielu inicjatyw podejmowanych przez poszczególne partie i organizacje. To tutaj w dniach 16-17 czerwca 1945 r. odbyła się konferencja „Ligi na Rzecz Pracującego Erec Izrael" gromadząca przeszło 250 delegatów i gości z wielu partii syjonistycznych. Jednocześnie odbyła się konferencja Bundu, na której $\mathrm{z}$ kolei starano się zachęcić do włączenia w odbudowę Polski. W czasie siedmiotygodniowego seminarium organizacji Hechaluc przygotowywano 40 instruktorów do pracy w organizacjach młodzieżowych i kibucach ${ }^{11}$.

Równolegle $\mathrm{z}$ działalnością polityczną, rozwijaniem różnych form pomocy oraz procesem produktywizacji $\mathrm{w}$ myśl przyjętej przez CKŻP idei przewarstwowienia Żydów, toczyło się życie kulturalne. Dosyć trudno byłoby ściśle wyznaczyć środowiska kulturalne Żydów w Łodzi ze względu na ich wzajemną przenikalność. Wyróżniała się z pewnością aktywność Związku Żydowskich Pisarzy i Dziennikarzy oraz organizacje skupiające malarzy które zostana omówione w dalszej części artykułu, podobnie jak i działalność teatru żydowskiego i produkcja wydawnicza. Zwornikiem życia kulturalnego Żydów w Polsce miało stać się powstałe w łodzi Żydowskie Towarzystwo Kultury. Warto jednak przyjrzeć się, choć pobieżnie, podejmowanym przez żydowskie organizacje, często przy udziale i jak należy sądzić, poparciu Wojewódzkiego Komitetu Żydowskiego. Przy organizacjach starano się organizować biblioteki i czytelnie. Pod koniec 1946 r. otwarto bibliotekę im. Borochowa w lokalu Domu Robotniczego im. L. Holenderskiego (Poalej Syjon Lewica), a 9 lutego 1947 r. w lokalu sekcji Haowed Hacijoni. W lokalu Haszomer Hacair przy ul. Śródmiejskiej 4 codziennie czynna była świetlica, w której wkrótce otwarto bibliotekę. Dostępne dla szerokiej publiczności były również Domy Kultury działające przy poszczególnych organizacjach. 15 października $1946 \mathrm{r}$. otwarto taki właśnie Dom przy organizacji Haszomer Hacair przy ul. Kilińskiego 49. Miał dać - jak zapewniała kierowniczka Domu dr Lubelska - „gościnę pisarzom, artystom i malarzom żydowskim, pozwolić ludności żydowskiej w Łodzi spędzić czas w atmosferze twórczej myśli syjonistycznej”. Podczas wieczoru inaugurującego referat o zdobyczach kulturalnych nowej Palestyny wygłosił przebywający wówczas w Polsce poeta Beniamin Tenenbaum. Wieczór zakończyły występy artystyczne, m.in. recital skrzypaczki Bronisławy Rotsztatówny ${ }^{12}$ oraz aktorek Eni Liton i Keti Efron ${ }^{13}$. Największa aktywność Domu Kultury przy Haszomer Hacair przypadała na koniec roku 1946 i pierwszą połowę $1947 \mathrm{r}$. Wielokrotnie odbywały się spotkania z poetami i pisarzami. 12 listopada 1946 r. miał miejsce wieczór twórczości Abrahama Suckewera,

${ }^{11}$ S. Grajek, Po wojnie i co dalej. Żydzi w Polsce w latach 1945-1949. Warszawa 2003, s. $41,59$.

${ }^{12}$ Bronisława Rotsztatówna była rodowitą łodzianką. Wojnę spędziła w getcie łódzkim, gdzie występowała jako skrzypaczka podczas koncertów i rewii.

13 „Mosty” 1946, nr 1, s. 4. 
a 26 listopada tegoż roku - Władysława Broniewskiego, na którym Beniamin Tenenbaum opowiadał o pobycie poety w Palestynie w czasie wojny, w grudniu natomiast - poety Józefa Rubinsztajna, ze słowem wstępnym Dawida Sfarda. Rok 1947 rozpoczęto wieczorem na temat Dziecko oskarża, na którym omawiano skutki przeżyć wojennych u dzieci i zalecane metody wychowawcze. W lutym zorganizowano wieczór poświęcony literaturze dla dzieci i młodzieży, ze słowem wstępnym Efraima Kaganowskiego oraz prasie żydowskiej, prowadzony przez Stefana Gelbarta. Wspomnieć warto jeszcze o dwóch spotkaniach autorskich - w czerwcu 1947 r. z Arturem Sandauerem oraz 1 stycznia 1948 r. z Jeszajahu Szpiglem. Szpigiel był jednym z niewielu pisarzy pochodzących z Łodzi, którego wiele nowel poświęconych było życiu w getcie łódzkim.

Organizacje społeczne i polityczne w Lodzi wykorzystywały praktycznie każdą możliwą okoliczność do organizowania akademii, wieczorów poświęconych rocznicom, osobom i wydarzeniom. Patrząc na ten rodzaj aktywności wydaje się, że często była to próba podniesienia statystyki spotkań, co szczegółowo odnotowywano w Wojewódzkim Komitecie Żydowskim w Łodzi. Świętowano, zgodnie z duchem czasu, rocznice rewolucji październikowej.

Podczas uroczystej akademii świętowano dwulecie Komitetu Żydowskiego w Łodzi w lutym 1947 r., na której obok żydowskich działaczy pojawili się przedstawiciele władz miasta i władz partii politycznych. W części artystycznej udział wzięli artyści żydowscy: Eni Liton, Judyta Berg, Feliks Fibich, Bronisława Rotsztatówna i Nadi Kareni.

Warto zwrócić uwagę na obchodzone uroczystości upamiętniających likwidację gett w czasie wojny. Oczywiście na pierwszym plan wybijają się corocznie uroczystości poświęcone powstaniu w getcie warszawskim. Na łamach prasy żydowskiej ukazywały się wówczas apele o zbiórkę funduszy na pomnik Bohaterów Getta, artykuły wspomnieniowe, wiersze. Organizowano również akademie upamiętniające likwidację getta w Wilnie, Radomiu i Białymstoku. Organizowane były najczęściej przez ziomkostwa $\mathrm{z}$ danych miejscowości.

Pamiętano również o kolejnych rocznicach likwidacji getta łódzkiego. Myślę, że z kronikarskiego obowiązku warto jest poświęcić tym wydarzeniom kilka słów. Organizatorami uroczystości 28 września 1947 r., a więc w trzecią rocznicę likwidacji były: WKŻ w Łodzi, Żydowska Kongregacja Wyznaniowa i Ziomkostwo Łodzian. Przybyło na nią kilka tysięcy mieszkańców oraz przedstawiciele władz miasta i partii politycznych. Pierwsza częśc uroczystości miała miejsce na cmentarzu żydowskim, gdzie odsłonięto tablicę ku czci pomordowanych i odprawiono modły. Przemawiali: przewodniczący Miejskiej Rady Narodowej - Andrzejak, wiceprezes CKŻP - Salo Fiszgrund, przewodniczący Kongregacji Wyznaniowej - Józef Atlas oraz w imieniu Ziomkostwa Łodzian - Chludniewicz. Uroczysta akademia zorganizowana została natomiast w Teatrze Wojska Polskiego, gdzie wystąpienia poświęcone łódzkim Żydom mieli Szymon Rogoziński, Salo Fiszgrund, przedstawiciel prezydenta miasta Jagodziński i Wolf Jasny. W części artystycznej wystąpili: Ida Kamińska, Meir 
Melman, pianista Aleksander Tabaksblat oraz chór pod dyrekcją Frydlanda ${ }^{14}$. W czwartą rocznicę likwidacji getta łódzkiego uroczystości odbyły się jedynie na cmentarzu. Przy odsłoniętej rok wcześniej tablicy odbyły się uroczystości żałobne, które rozpoczął przewodniczący WKŻ - Michał Mirski. Głos zabrał też jeden $\mathrm{z}$ ocalonych z getta, Fogel, który przybliżył zgromadzonym losy Żydów $\mathrm{w}$ czasie wojny w Łodzi. W imieniu Kongregacji Wyznaniowej przemawiał Bursztajn, a Ziomkostwa - poeta Chaim Fuks ${ }^{15}$. W kolejnym roku odbyła się natomiast uroczystość położenia kamienia węgielnego pod pomnik poświęcony pamięci męczenników getta. Ponownie uroczystości na cmentarzu otworzył M. Mirski, po nim przemawiała przedstawicielka PZPR w Łodzi - Papierowa, przedstawiciel Wojska Polskiego - mjr Czerwiński i członek prezydium WKŻ Sz. Rogoziński. W imieniu Kongregacji głos zabrał Rajak, a całość uroczystości zakończono odegraniem marsza żałobnego Szopena i hymnu państwowego ${ }^{16}$.

\section{Związek Literatów i Dziennikarzy Żydowskich w Lodzi}

Zdecydowana większość ludzi pióra przeżyła wojnę w ZSRR. Ocaleni żydowscy pisarze i dziennikarze zaczęli się grupować już w Lublinie jesienią $1944 \mathrm{r}$. wokół Tymczasowego Centralnego Komitetu Żydów Polskich. Było to przede wszystkim środowisko świeckich literatów tworzących w języku jidysz, skupionych przed wojną w legendarnym Związku Literatów i Dziennikarzy Żydowskich mieszczącym się w Warszawie przy ul. Tłomackie 13. Jedną z pierwszych inicjatyw podjętych przez powstający Związek było powołanie Żydowskiej Agencji Prasowej oraz rozpoczęcie wydawania w listopadzie 1944 r. biuletynu informacyjnego, który ukazywał się do grudnia 1949 r., trzy razy w tygodniu, zawierając krótkie informacje zarówno po polsku jak i w jidysz. Zanim jednak rozpoczęto regularny druk, biuletyn ŻAP był pisany ręcznie przez kalkę. Brak maszyn drukarskich odczuwany był dotkliwie przez społeczność żydowska, zwłaszcza wobec rosnącej potrzeby przekazu informacji poprzez regularnie ukazujące się gazety. Według niektórych dziennikarzy informacje o odnalezieniu żydowskiej maszyny drukarskiej w Łodzi zaważyły o osiedleniu się Związku w Lodzi. Jak wspominał Efroim Siedlecki, plotki o żydowskiej drukarni dotarły do Lublina w styczniu, a więc tuż po wyzwoleniu miasta. Do Łodzi wysłana została grupa literatów w celu zweryfikowania informacji. Rzeczywiście znaleźli oni w ruinach getta rozsypaną maszynę drukarską, którą przenieśli do pustego lokalu przy ul. Narutowicza $32^{17}$. Wkrótce do Łodzi przybyli pozostali członkowie Związku, a miejsce złożenia składu zecerskiego stało się jego siedzibą. Jest to z pewnością bardzo obrazowe i symboliczne wyjaśnienie powodów pojawienia się literatów w Łodzi, zwłaszcza mając na uwadze, że rozsypana maszyna

14 „Mosty” 1947, nr 64, s. 4.

15 "Mosty” 1948, nr 108, s. 4.

16 „Mosty” 1949, nr 28, s. 5.

${ }^{17} \mathrm{~N}$. Cohen, The renewed Associaton of Jewish writers and journalists In Poland 1944-1948, [w:] Yiddish after the Holocaust, ed. by J. Sherman, Oxford 2004. 
wcześniej służyła w getcie łódzkim do drukowania „Getocajtung” oraz akcydensów na potrzeby żydowskiej administracji getta. Trzeba jednak pamiętać, że do Łodzi ciagnęły wówczas thumy ocalałej ludności żydowskiej przez co, siłą rzeczy stawała się ona centrum życia politycznego i kulturalnego, tak samo jak przyjęła na siebie $\mathrm{w}$ zastępstwie zrujnowanej Warszawy nieformalną funkcje stolicy państwa. Pierwsi pojawiający się w Łodzi działacze kultury zaczęli przybywać najczęściej w mundurach wojska polskiego. Byli wśród nich Rachela Auerbach, Lejb Olicki, Jonas Turkow, Jehuda Elberg, Natan Gross, Mendel Mann, Michał Mirski, Efroim Siedlecki ${ }^{18}$. Skupili się oni formalnie w Związku Żydowskich Pisarzy, Dziennikarzy i Aktorów w Polsce (Farajn fun Jidisze Literatn, Żurnalistn un Artistin In Pojlin), z siedzibą w lokalu przy ul. Narutowicza 32. Jeden z przedwojennych jego członków, Mosze Nudelman, nawoływał: „życzę naszym kolegom pisarzom, żeby zapamiętali sobie numer 'mieszkania' naszego Związku. Narutowicza 32 lokal 9 powinno choć w miniaturze odzwier-

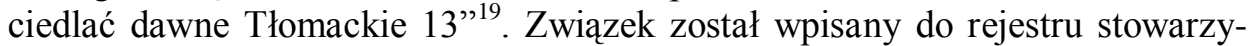
szeń i związków Zarządu Miejskiego w Łodzi pod numerem 107 nosząc oficjalną nazwę Związek Literatów i Dziennikarzy Żydowskich w Lodzi. Oficjalne otwarcie siedziby przy ul. Narutowicza 32 odbyło się 14 kwietnia 1946 r. w obecności zarówno żydowskich organizacji, jak i polskich pisarzy, których reprezentował Władysław Broniewski ${ }^{20}$.

W zatwierdzonym statucie siedzibą i terenem działalności stowarzyszenia była Łódź. Dopiero w kwietniu 1948 r. formalnie zmieniono nazwę na Związek Literatów i Dziennikarzy Żydowskich w Polsce ${ }^{21}$, a terenem działalności stał się „obszar całego Państwa Polskiego”. Jednocześnie umożliwiono tworzenie za zgodą Zarządu Głównego oddziałów terenowych Związku w każdej miejscowości, w której znajdzie się 10 dziennikarzy i literatów żydowskich ${ }^{22}$.

Członkiem Związku mógł być każdy, kto wydał 10 utworów w języku hebrajskim lub w jidysz, bądź był autorem uznanej książki albo thumaczenia. Trudno jest podać dokładną liczbę członków Związku, ponieważ bardzo szybko ulegała ona zmianie wskutek masowej emigracji z Polski. W sierpniu 1945 r. należało do niego 56 osób, w tym członkowie Żydowskiej Komisji Historycznej, która wówczas również była jego częścią. Jak nieliczna była to grupa wystarczy przytoczyć dane z końca 1929 r., kiedy to Związek liczył 269 osób, z których

${ }^{18}$ L. Olejnik, Spoleczność żydowska w Lodzi 1945-1950. Zarys problemu, „Acta Universitatis Lodziensis - Folia Historica" 1997, nr 60, s. 137.

${ }^{19}$ M. Nudelman, A gelechter durch trern, Buenos Aires, 1947, s. 147.

${ }^{20}$ „Dos Naje Lebn”, 1946, nr 16, s. 2.

${ }^{21} \mathrm{Na}$ papierach firmowych i pieczątkach Związku określenie „w Polsce” widniało już w $1947 \mathrm{r}$.

${ }^{22}$ APŁ, ZMŁ 162, k. 39, 55-56. 
188 mieszkało w Warszawie ${ }^{23}$. W kwietniu 1946 r. należało do niego jedynie 29 członków, co w dużej mierze było spowodowane opuszczeniem grupy aktorów, którzy założyli własny Związek. Fala repatriacyjna po wydarzeniach kieleckich w lipcu 1946 r. zabrała kolejnych, przez co liczba zweryfikowanych członków w sierpniu 1946 r. wynosiła jedynie 15 osób ${ }^{24}$. Pod koniec 1947 r. do Związku należały 44 osoby i 5 kandydatów, a w maju 1948 r. - 37 członków i 5 kandydatów ${ }^{25}$. Pierwszy prezes Związku, Jonas Turkow, wyjechał jako jeden z pierwszych już jesienią $1945 \mathrm{r}$.

Podstawowym zadaniem Związku było dostarczanie pomocy materialnej jego członkom, zwłaszcza repatriantom. Każdy pisarz wracający ze Związku Radzieckiego otrzymywał kwotę 5000 zł na najważniejsze wydatki i zostawał dopisany do długiej listy członków i ich rodzin otrzymujących miesięczne stypendium, darmowy posiłek, odzież, podstawowe meble, tymczasową siedzibą oraz pomoc w znalezieniu stałego miejsca zamieszkania ${ }^{26}$. Związek utrzymywał się natomiast dzięki finansowej pomocy CKŻP i łódzkiego WKŻ oraz pomocy zagranicznej, przede wszystkim płynącej z amerykańskiego Joint Distribution Committee. Rozkład tej pomocy wyraźnie widać w świetle przedstawionego przez Związek w Zarządzie Miasta Łodzi preliminarzu budżetowym na rok 1948: wpływy od amerykańskiej organizacji Joint przewidywane były na 2400000 zł, kwota (1 000 000) miała zostać przekazana przez CKŻP. Znikome natomiast były wobec tych kwot wpływy ze składek członkowskich (48 000) oraz ze sprzedaży miesięcznika „Jidisze Szriftin” $(120000)^{27}$.

Poza pomocą materialną Związek starał się umożliwić członkom publikowanie, głównie w pierwszym żydowskim czasopiśmie ukazującym się w Polsce, a więc „Dos Naje Lebn”, miesięczniku literackim „Jidisze Szriftin” oraz w wydawnictwie „Jidisze Buch”. Wielu spośród literatów było zatrudnionych w redakcjach tych wydawnictw, podobnie jak w ukazujących się wówczas w Łodzi czasopismach żydowskich, zarówno w języku polskim („Mosty”, „Opinia”) jak i jidysz. Misją pisarzy było przede wszystkim upamiętnienie Holocaustu, niemniej podejmowano również próby odnowienia oblicza literatury żydowskiej. Podobnie jak i we wszystkich dziedzinach życia żydowskiego

${ }^{23}$ N. Cohen, Motywy emigracji pisarzy żydowskich z Polski w latach 1945-1948, [w:] Nusech Pojln. Studia z dziejów kultury jidysz w powojennej Polsce, pod red. M. Ruty, Kraków 2008, s. 232.

${ }^{24}$ Byli to: Leo Finkelsztajn, Nuchen Bomze, Mojżesz Grosman, Icchak Jonasowicz, Josef Rubinsztajn (wszyscy zamieszkujący lokal na ul. Piramowicza 8), Ber Mark, Abraham Zak, Szmul Kaczerginski, Chaim Grade, Lajb Olicki (bursa na ul. Franciszkańskiej 15), Ozjasz Szlajen i Mosze Knapajs (ul. Sienkiewicza 37), Jakob Zineman (ul. Jaracza 23), Nachan Blic (Al. Kościuszki 98) oraz Marek Nudelman (Narutowicza 32) - APŁ, ZMŁ, 162, k. 79.

${ }^{25}$ APŁ, ZMŁ 162, k. 58 (Lista członków Związku); „Mosty” 1947, nr 73, s. 4; 1948, nr 61, s. 8.

${ }^{26}$ Archiwum Żydowskiego Instytutu Historycznego [dalej AŻIH], CKŻP/202. List Związku do Centralnej Komisji z 13 V 1946 r. oraz protokoły posiedzeń.

${ }^{27}$ APŁ, ZMŁ, 162, k. 59. 
zadania $\mathrm{i}$ rola literatury żydowskiej odzwierciedlały postawy funkcjonujące wśród polskich Żydów, które sprowadzić można do odpowiedzi na dwa pytania: czy odbudować życie żydowskie w Polsce czy w Palestynie oraz czy budować nowoczesną, świecką społeczność czy też odwoływać się do tradycji, lub wręcz do postawy religijnej.

W czasie Walnego Zgromadzenia Związu Literatów i Dziennikarzy Żydowskich w Łodzi, które odbyło się w dniach 25-26 października 1947 r., wyraźnie akcentowana była konieczność bliskiej współpracy literatury żydowskiej i polskiej. Tematowi bliskich więzów obu literatur poświęcone było wystąpienie wiceprzewodniczącego Związku Bera Marka, otwierające spotkanie ${ }^{28}$. Podkreślił je też w swoim referacie przewodniczący oddziału łódzkiego Związku, Seweryn Pollak. Na zebraniu przestawiono również sprawozdanie z 17 miesięcy funkcjonowania Związku oraz wybrano jego nowe władze. Do nowego Zarządu weszli Ber Mark jako przewodniczący, Rachela Auerbach - wiceprzewodnicząca, Abraham Zak - sekretarz, Chil Hefer - skarbnik oraz Michał Mirski, Fiszel Hercberg i Izrael Aszendorf jako członkowie ${ }^{29}$. Zastępcami zostali Chaim Lejb Fuks, dr Kanter i Horacy Safrin. Honorowym prezesem Związku został wybrany Efraim Kaganowski. To jemu też przypadł zaszczyt odsłonięcia tablicy upamiętniającej 400 zamordowanych pisarzy żydowskich z Polski ${ }^{30}$.

Trzecie walne zebranie Związku odbyło się 21 maja 1948 r. Podsumowując działalność Ber Mark pokreślił, że mimo nielicznego składu (37 członków i 5 kandydatów) Związek ,stanowi zwarty kolektyw postępowych pisarzy, mogący poszczycić się sporym dorobkiem $\mathrm{w}$ dziedzinie powojennej literatury żydowskiej". Dalsze przemówienia i rezolucje nie pozostawiają złudzeń, co do kierunku, w którym podąża Związek. Oto przewodniczący CKŻP Hersz Smolar witając zebranych podnosi „ważką rolę bojowników pióra w dziele kształtowania oblicza kulturalnego żydostwa polskiego” i uważa, że pisarze „powinni walnie przyczynić się do stworzenia frontowej pozycji w walce o postęp, braterstwo narodów i trwały pokój na świecie". Z kolei B. Mark w referacie Zasadnicze problemy literatury żydowskiej wyznaczył stojące przed pisarzami żydowskimi zadania, a więc włączenie się w walkę o pokój światowy, rozwijanie literatury $\mathrm{w}$ duchu socjalistycznego realizmu i niezasklepianie się w kręgu krasomówstwa, lecz kształtowanie nowej rzeczywistości, w której pisarz zajmuje pozycję ,inżyniera duszy”. Centralnym zagadnieniem ma być walka o założenie zrębów prawdziwej wolności i socjalizmu. Mark przeciwstawia mistycyzmowi, irracjonalizmowi i pesymizmowi panoszącemu się w literaturze żydowsko-amerykańskiej „świadomą swego posłannictwa rolę pisarza radzieckiego"31. W sprawozdaniu z działalności ustępującego Zarządu za 19-miesięcy

\footnotetext{
${ }^{28}$ B. Mark, O wspótpracy literatury żydowskiej i polskiej, „Mosty” 1947, nr 73, s. 4.

${ }^{29}$ APŁ, ZMŁ, 162, k. 67.

30 „Mosty” 1947, nr 72, s. 4.

31 „Mosty” 1948, nr 61, s. 3.
} 
sekretarz Związku Jeszajahu Szpigiel wymienił około 30 imprez literackich, między innymi w ramach ogłoszonego w styczniu 1948 r. Miesiąca Kultury Żydowskiej, udział w licznych akcjach politycznych oraz rozwijanie pomocy materialnej wśród pisarzy. Do nowych władz wybranego podczas zebrania Zarządu weszli Binem Heller, Ber Mark, Michał Mirski, Lejb Olicki, Horacy Safrin, Dawid Sfard, Jeszajahu Szpigiel oraz Guta Guterman i Lejb Morgentau jako zastępcy ${ }^{32}$.

Wśród bardziej znaczących wydarzeń organizowanych przez Związek mieścił się wieczór młodych pisarzy, który odbył się 25 marca 1948 r. Swoje utwory czytało i przedstawiało sześciu młodych twórców: poeci Natan Gross, Perl Halter, Szlomo Micmacher i Wolf Pasmanik oraz prozaicy Dawid Hofnung i Rywa Kwiatkowska, którzy przedstawili fragmenty swoich opowiadań o życiu w getcie ${ }^{33}$. Nad twórczością ,młodych” dyskutowali dojrzali literaci, m.in. Ber Mark, Michał Mirski, Chaim Lejb Fuks, Salomon Lastik, Aszendorf ${ }^{34}$.

W listopadzie 1948 r. w siedzibie Związku odbyło się spotkanie promujące tomik wierszy Guty Guterman Des Opgrund rojszt (Otchłań wre). Spotkanie prowadził J. Szpigiel, a oceny poezji dokonali D. Sfard i B. Heller, podkreślając realizm, prostotę $i$ afirmację zawartą w wierszach ${ }^{35}$.

Wśród żydowskich pisarzy widoczne były dwie postawy - jedni masowo opuszczali Polskę, nie chcąc mieszkać na cmentarzu polskiego żydostwa, w dodatku napotykając na wiele przejawów antysemityzmu Polaków, inni uważali za swój obowiązek odbudowę życia kulturalnego, upamiętnianie katastrofy swojego narodu i upamiętnianie jej śladów dla Żydów na całym świecie. W tej drugiej grupie było wiele osób powracających ze Związku Radzieckiego, z ugruntowanym światopoglądem komunistycznym. Dla nich wyzwaniem stało się nie tylko odbudowanie kultury żydowskiej, ale i odnowienie jej oblicza w duchu nowej ery, na wzór kultury sowieckiej. Nie wszyscy jednak wytrwali $\mathrm{w}$ realizacji tych zamierzeń, zwłaszcza przy zaostrzającym się stosunku władz komunistycznych wobec autonomii społeczności żydowskiej. Dla ludzi żyjących z pisania problemem stało się zdobycie środków do życia wobec malejącego grona odbiorów. Pisarze niemal nic nie dostawali za swoje publikacje, ukazywało się niewiele książek, bo nie było na nie chętnych czytelników, a po sześcio- czy siedmiokrotnym wystawieniu sztuki nie było już jej dla kogo grać ${ }^{36}$. Emigracja stawała się więc rozwiązaniem nie tylko z przyczyn politycznych i moralnych, ale również ekonomicznych. Pod koniec 1948 r., a więc w okresie gdy większość instytucji i działaczy opuściła Łódź, żydowskie

\footnotetext{
${ }^{32}$ Ibidem.

${ }^{33}$ Rywa Kwiatkowska kończyła właśnie powieść Fun lager in lager o ostatnich miesiącach łódzkiego getta, która zostało wydane w 1950 r. w Buenos Aires. Sama autorka przebywała już wówczas w Izraelu.

${ }^{34}$ „Mosty” 1948, nr 38, s. 8.

35 "Mosty" 1948, nr 137, s 7.

${ }^{36}$ N. Cohen, op.cit., s. 237.
} 
środowisko literackie w Polsce składało się głównie z funkcjonariuszy politycznych lub tych, którzy akceptowali dyktat władzy ${ }^{37}$.

Związek funkcjonował oficjalnie w Łodzi do 26 października 1950 r., kiedy to skreślony został z rejestru stowarzyszeń z powodu przeniesienia siedziby do Warszawy. Decyzję taką podjęto na mocy uchwały Zarządu z 30 kwietnia tegoż roku $^{38}$.

\section{Działalność wydawnicza}

Wraz z zagoszczeniem w Łodzi Centralnej Żydowskiej Komisji Historycznej rozpoczęto prace nad publikacjami, w głównej mierze poświęconych upamiętnieniu Zagłady. Pierwsze książki CŻKH ukazały się w j. polskim, wobec braku możliwości drukowania w jidysz. Dopiero dzięki pozbieranemu w ruinach getta składowi zecerskiemu uruchomiono pierwszą powojenną drukarnię żydowską. Pracę w niej wspominał po latach łodzianin, Aleksander Klugman: „Ktoś mi powiedział, że w drukarni potrzebni są robotnicy. Udałem się pod wskazany adres: Drukarnia Państwowa nr 10 przy ul. Narutowicza 32. Ku mojemu zaskoczeniu kierownik zapytał, czy znam język żydowski. Okazało się, że to jedyny zakład poligraficzny w Polsce, w którym drukuje się różne wydawnictwa w języku żydowskim"39. Pod koniec 1945 r. drukarnia została wyposażona w nowoczesne linotypy, przysłane przez amerykański związek zawodowy drukarzy. Drukarnia funkcjonowała w Łodzi do przełomu lat 1947/1948, kiedy to została przekształcona $\mathrm{z}$ jednostki państwowej $\mathrm{w}$ jednostkę należącą do wydawnictwa "Nowe Życie” i przeniesiona wraz z całym wydawnictwem do Warszawy.

Bardzo szybko podjęto decyzję o wydawaniu własnej gazety - 10 kwietnia 1945 r. ukazał się w Łodzi pierwszy numer „Dos Naje Lebn” („Nowe Życie”), która do 1947 r. była wspólnym organem CKŻP i Związku Żydowskich Literatów, Dziennikarzy i Artystów w Polsce ${ }^{40}$. Pismo osiagnęło w 1946 r. nakład 10 tys., ukazywało się dwa razy w tygodniu.

Literaci żydowscy odczuwali coraz silniejszą potrzebę stworzenia czasopisma literackiego, zarówno jako miejsca publikacji swoich utworów jak i sposobu na zarabianie pieniędzy. Mimo kłopotów ze znalezieniem funduszy Związkowi udało się w listopadzie 1946 r. opublikować pierwszy numer miesięcznika literackiego „Jidisze Szriftin - cajtszrift far literatur, teater un kultur”. W skład redakcji weszli A. Zak, B. Mark, M. Mirski, D. Sfar, L. Finkelsztajn i E. Kaganowski. Czasopismo ukazywało się do września 1968 r. (250 nume-

\footnotetext{
${ }^{37}$ Ibidem, s. 246.

${ }^{38}$ APŁ, ZMŁ 162, k. 32, 34.

${ }^{39}$ T. i A. Klugman, A droga wiodła przez Łódź, Łódź 2004, s. 69.

${ }^{40}$ M. Horn, Działalność naukowa $i$ wydawnicza CŻKH przy CKŻwP $i \dot{Z} I H$ w Polsce $w$ latach 1945-1950. „Biuletyn Żydowskiego Instytutu Historycznego” (dalej BŻIH), 1985, nr 1-2, s. 123-132.
} 
rów) ${ }^{41}$. Związek opublikował także dwie antologie pod tym samym tytułem: pierwszy zeszyt ukazał się $\mathrm{w}$ połowie 1946 r., a drugi w połowie 1948 r. Redaktorem pierwszego almanachu był L. Finkelsztajn. Tematycznie poświęcony był upamiętnieniu Zagłady i stanowił swojego rodzaju Księgę Pamięci. Do współpracy nad redagowaniem tomu, określanego jako Księga Pamiątkowa i Księga Męczeństwa, nawoływała w apelu kierowanym do ogółu Żydów, a szczególnie do pisarzy i dziennikarzy żydowskich, Centralna Żydowska Komisja Historyczna. Proszono o dostarczanie informacji o życiu w czasie wojny i śmierci historyka Szymona Dubnowa, prof. Noacha Pryłuckiego, badacza literatury Nachmana Szapiro, literatów J. Perle, Z. Kalmanowicza, Hillela Cajtlina, S. J. Imbera i innych ${ }^{42}$. Na początku almanachu zamieszczono listę z nazwiskami 262 pisarzy zamordowanych w czasie wojny, uzupełnioną fotografiami 13 twórców rozsianymi po całym zbiorze. Tom zawierał utwory 37 autorów $^{43}$, praktycznie wszystkich żyjących wówczas w Polsce pisarzy żydowskich. Wydanie almanachu uczczono specjalną akademią w łódzkim Teatrze Żydowskim 26 października 1946 r., na której publikację przedstawił redaktor Leo Finkelsztajn. Przemawiali również Ber Mark i Efraim Kaganowski, a kilku spośród autorów czytało swoje utwory. Część artystyczna oddana został aktorom teatru - Nadi Kareni, Eni Liton, Mojżeszowi Lipmanowi i J. Kurlenderowi ${ }^{44}$.

Drugi numer almanachu ukazał się w połowie 1948 r. pod redakcją Izraela Aszendorfa, Binema Hellera i Lejba Olickiego. W almanachu opublikowano utwory 43 twórców, przy czym aż $23^{45}$ nazwiska nie pojawiły się w pierwszym tomie. Wyraźnie widać, jak wiele osób opuściło w tym okresie Polskę, skoro zabrakło 17 autorów.

Oba tomy almanachu miały podobną konstrukcję - obok wspomnień, recenzji i artykułów o literaturze oraz tekstów propagandowych, zamieszczono działa literackie. W tomie drugim jest więcej utworów poetyckich oraz dwie jednoak-

${ }^{41}$ N. Cohen, op.cit., s. 25.

42 „Opinia” 1946, nr 2, s. 10

${ }^{43}$ Byli to Izrael Aszendorf, Rachela Auerbach, Szlojme Berliński, Pesach Binecki, Nachum Bomze, Juda Elberg, Chaim Grade, Mojsze Grosman, Leo Finkelsztajn, Chaim Lejb Fuks, Guta Guterman, Binem Heller, Wolf Hersz Iwan, Icchak Jonasowicz, Szmerke Kaczergiński, Efraim Kaganowski, Mojsze Knajhejs, Rachela Korn, Lejb Kuperszmidt, Mendel Man, Ber Mark, Michał Mirski, B. Mosiężnik, Mojsze Nudelman, Josef Okrutny, Mordechaj Olej, Mates Olicki, Lejb Olicki, Ichcak Perlow, Josef Rubinsztajn, Dawid Sfard, Abraham Suckewer, Jeszajahu Szpigiel, Mojsze Waldman, Josef Wolf, Abraham Zak, Rejzl Żychlińska - M. Ruta, Tematy literatury jidysz w latach 1945-1949, [w:] Nusech Pojln, op.cit., s. 250.

44 „Mosty” 1946, nr 4, s. 4.

${ }^{45}$ Byli to: Artur Ajzenbach, Ichcak Barnsztajn, Mordechaj Bernsztajn, Nachman Blumental, Ichcak Guterman, Perl Halter, Jechiel Hofer, Dawid Hofnung, Wolf Jasny, Icchak Kanter, Ber Kuczer, Riwka Kwiatkowska, Szlojme Łastik, Szlojme Mincmacher, Lej Morgentoj, Wolf Pasmanik, Nachmann Ropp, Hadasa Rubin, Horacy Safrin, Hersz Smolar, Mojsze Szklar, Elchanan Wogler, Janker Zonsztajn - M. Ruta, op.cit., s. 253. 
tówki. Rozszerza się również zakres tematów, choć w dalszym ciągu dominują wattki martyrologiczne.

Tematyka Zagłady dominuje również w dwóch pierwszych rocznikach „Jidisze Szriftin". Dopiero od końca 1948 r. rozszerza się zakres tematów, m.in. o motyw niepodległości państwa Izrael. Ponieważ większość twórców spędziła wojnę w Związku Radzieckim i najczęściej nie doświadczyła Zagłady osobiście, ciekawie jawi się dyskusja między nimi a tymi, którzy wojnę spędzili w gettach. Najpełniejszy obraz znalazła ona w poemacie łódzkiego pisarza Jeszejahu Szpigla z 1947 r. pt. Pożegnanie. Jest to rozmowa dwóch Żydów, z których jeden przeżył wojnę $w$ getcie a drugi w ZSRR. Repatriant, mimo rozpaczy na wieść o tragedii polskich Żydów i śmierci żony i dziecka, próbuje na nowo odnaleźć sens życia, podczas gdy Żyd z getta uważa, że nie jest on w stanie zrozumieć doświadczeń tych, które przeszły przez to piekło, nie zgadza się z poglądem, że nie ma takiego zła, którego nie można by naprawić. Boli go zarzucanie ludziom z getta, że pozwolili się zhańbić bezwolnie idąc na śmierć, uważa takie myślenie za profanację pamięci zmarłych. Nie wierzy też w działanie opatrzności w postaci bohaterskiej Armii Czerwonej, która niby przyniosła ocalenie. Dla niego naturalną droga jest jednak opuszczenie kraju ruin, gdzie nie odnajdzie spokoju. Wizja świadka, którym był Szpigiel, zdobywała jednak mniejsze uznanie krytyków, dla których istotniejsze stało się podkreślanie bohaterskich postaw w czasie wojny, jak choćby w czasie powstania w getcie warszawskim.

Wraz ze zmieniającą się sytuacją w Polsce w miesięczniku „Jidisze Szriftin” coraz częściej pojawiały się teksty o wydźwięku ogólnoludzkim, a od 1949 r. wręcz o charakterze propagandowym ${ }^{46}$.

\section{Związek Żydowskich Artystów Plastyków}

Środowisko żydowskich plastyków i malarzy równie mocno, co pozostałą ludność, dotknęła Zagłada. Większość ocalałych uratowała się na terenie Związku Radzieckiego i wraz z kolejnymi falami repatriacyjnymi powracała do Polski, gdzie pierwszym przystankiem najczęściej była Łódź. Już na początku lipca 1946 r. przybył tu wybitny rzeźbiarz Natan Rapaport, rozpoczynając od razu studia do pomnika Getto ${ }^{47}$. Jednocześnie z nim powrócił z Samarkandy artysta-malarz Maurycy Bromberg ${ }^{48}$ oraz rzeźbiarka Sara Gorsztajn ${ }^{49}$. W tym czasie zamieszkał też $\mathrm{w}$ Łodzi twórca neorenesansu żydowskiego prof. Perec (Paweł) Willenberg ${ }^{50}$. Po tragicznych przejściach wojennych, deklarował on co

\footnotetext{
${ }^{46}$ M. Ruta, op.cit., s. 274.

47 „Opinia”, 1946, nr 1, s. 10. Pomnik Bohaterów Getta w Warszawie został odsłonięty 19 kwietnia $1948 \mathrm{r}$.

${ }^{48}$ Ibidem.

49 „Opinia” 1946, nr 4, s. 10

${ }^{50}$ Paweł Willenberg urodził się w r. 1874 w Makowie Mazowieckim. Ukończył Akademię Sztuk Pięknych w Petersburgu, następnie w Warszawie; uczeń Wojciecha Gersona. W 1913 r.
} 
prawda wolę spędzenia ostatnich lat życia wraz z synem $\mathrm{w}$ Palestynie, ale pozostał w Łodzi, gdzie umarł 17 lutego 1947 r. (pochowany został na łódzkim cmentarzu żydowskim). W czasie trzech lat życia w Łodzi Willenberg aktywnie uczestniczył w życiu łódzkiej społeczności malarzy, pozostawiając po sobie około 100 obrazów $^{51}$. Niektóre rysunki poświęcił ruinom getta łódzkiego. np. datowany na 1945 rysunek przedstawiający ślad po synagodze na ścianie budynku $^{52}$. Willenberg wszedł $\mathrm{w}$ skład tymczasowego zarządu reaktywowanego dzięki staraniom M. Bromberga w lipcu 1946 r. Żydowskiego Związku Artystów Plastyków $\mathrm{z}$ siedzibą $\mathrm{w}$ Łodzi. Obok niego w zarządzie zasiedli N. Rapaport i M. Bromberg. Związek liczył wówczas 20 członków, a jego pierwszym znaczącym przedsięwzięciem miała być wystawa zbiorowa, poświęcona przede wszystkim tematyce wielkiej tragedii polskiego żydostwa ${ }^{53}$. Zanim do niej doszło w lipcu tegoż roku została otwarta w lokalu Związku wystawa rysunków M. Bromberga ${ }^{54}$, a 18 września otwarta została zbiorowa wystawa grupy artystów skupionych w Spółdzielni Pracy Polskich Artystów Plastyków (?) w Łodzi, m.in. Maurycego Bromberga, Albina Łubniewicza, Macieja Nehringa. Na otwarciu wystawy pojawił się m.in. wiceprezydent Łodzi Eugeniusz Ajnenkiel oraz rektor Uniwersytetu Łódzkiego Tadeusz Kotarbiński. 20 września 1946 r. otwarta została w Sali Domu Kultury Haszomer Hacair (ul. Kilińskiego 49) wystawa Rafała Mandelzweiga pt.: „Martyrologia ludzka 1939-1945, ${ }^{5}$. Zbiorowa wystawa łódzkich malarzy należących do Grupy Plastyków-Żydów w Łodzi, Polskiego (prawdopodobnie tak określano wspomniany wcześniej Związek Artystów Plastyków) została otwarta 11 stycznia 1948 r. w ramach miesiąca kultury żydowskiej. Otwarcie wystawy dokonał prezydent - Łodzi Stawiński, a przemawiali m.in. Efaim Kaganowski w imieniu Centralnego Żydowskiego Towarzystwa Kultury (który zreszta, również wystawił własne prace malarskie), Gurwicz z WKŻ i A. Boden $\mathrm{w}$ imieniu plastyków ${ }^{56}$. Kaganowski podkreślił, że pomocy przy otwarciu wystawy udzieliło niedawno utworzone Żydowskie Towarzystwo Kultury, co

miał wystawę z Romanem Kramsztykiem, a w 1916 r. brał udział w wystawie zbiorowej z Wyspiańskim, Wyczółkowskim, Malczewskim i Hirszenbergiem. Prowadząc szkołę malarską w Częstochowie wyróżniony został medalem za zasługi pedagogiczne. Zmarły był przyjacielem Nauma Sokołowa, poświęcili mu artykuły Szalom Asz i Bałaban. W czasie wojny ukrywał się w Warszawie pod nazwiskiem Karol Baltazar Penkosławski. Malował obrazy i treści religijnej i udawał niemowę, gdyż miał wzbudzający podejrzenia akcent.

${ }^{51}$ W rocznicę śmierci prof. Willenberga, „Mosty” 1948, nr 21, s. 4.

${ }^{52}$ Rysunek został przedrukowany w „Opinii, 1946, nr 1, s. 7. W „Opinii” pojawiały się również okazjonalne ilustracje autorstwa Willenberga, np. epitafia Teodora Herzla, „Opinia” 1946, nr 2 , s. 3

53 "Opinia” 1946, nr 2, s. 10.

54 „Opinia” 1946, nr 1, s. 10

55 "Opinia” 1946, nr 5, s. 10.

56 „Opinia” 1947, nr 28, s. 9. 
stało się pierwszą publiczną jego aktywnością ${ }^{57}$. Wystawiono na niej 157 prac z dziedziny malarstwa, rzeźby, grafiki i metaloplastyki 22 autorów ${ }^{58}$. Jedna trzecia prac poświęcona była tematom wojennym, a na wyróżnienia zasługiwały przede wszystkim obrazy Sary Gliksman pokazujące getto łódzkie (np. Most w getcie tódzkim) czy Maurycego Bromberga (Oświęcim). Rok później prace 10 łódzkich artystów żydowskich zostały pokazane na wystawie w ramach IV Dorocznego Salonu Polskiego Związku Artystów Plastyków, co uznane zostało za ważny wkład w całokształt życia artystycznej Łodzi (na wystawie pokazano ogółem prace 70 osób). Warto jednak zauważyć, że były to prace najczęściej o neutralnej tematyce, brak było odwołań do tematyki narodowej i wojennej, natomiast pojawiały się akcenty mające odzwierciedlać „,rewolucyjny zwrot w polityce artystycznej" (Beniamin Pacanowski przedstawił np. rysunki $W$ odlewni metalu).

Inicjatywą zgodną $\mathrm{z}$ polityką zarówno władz komunistycznych jak i Wojewódzkiego Komitetu Żydowskiego, a właściwie działającego w jego ramach Wydziału Produktywizacji, było utworzenie w styczniu 1947 r. Spółdzielni Pracy Artystów Malarzy „Sztuka”, z siedzibą w Lodzi przy ul. Piotrkowskiej $42 \mathrm{~m}$ 30. Spółdzielnia, ciesząca się poparciem władz, miała stworzyć

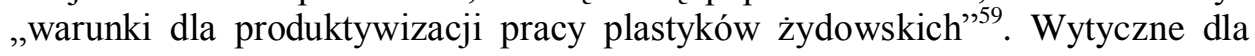
spółdzielni ujęto $\mathrm{w}$ dwóch podstawowych zadaniach: wykonywanie $\mathrm{w}$ ramach spółdzielni prac z dziedziny sztuki użytkowej oraz szkolenia młodych adeptów sztuki. Do pracy twórczej przygotowane zostało „Studio”, gdzie prowadzić miano zajęcia malarsko-rzeźbiarskie, grafikę użytkową, ceramikę, batikowanie i papier mache. Spółdzielnia zajmowała trzy przestronne lokale przy ul. Piotrkowskiej 42. Na przewodniczącego Rady Nadzorczej wybrano wówczas już poważnie chorego P. Willenberga. Do zarządu weszli Baniamin Pacanowski jako przewodniczący, Henryk Hechtfopf (sekretarz) i Józef Fajngold (sekretarz). Spółdzielnia obejmowała w momencie powstania kilkunastu członków, a byli to oprócz wspomnianych wyżej: Mojżesz Bekerman, Maurycy Bromberg, Juliusz Edelman, Teodor Gelb, Sara Gersztajn, Sara Gliksman, Mojżesze Lubliński, Jezechiel Mucznik, Aron Muszka, Karol Piasecki, Izaak Rajzman i Dorota Szenfeld $^{60}$.

${ }^{57}$ E. Kaganowski, Impresje z wystawy Żydowskich Artystów Plastyków, „Opinia” 1948, nr 30, 25 II, s. 9.

${ }^{58}$ Byli to: Mojżesz Bekerman, Aleksander Bogen, Maurycy Bromberg, Józef Fajngold, Szymon Fogelman, Sara Gliksman, Sara Gorsztajn, Rachmil Gryner, Efraim Kaganowski, Mosze Lubiński, Jecheskiel Mucznik, Aron Muszka, Natan Gutman, Henryk Hechtkopf, Halina Olszewska, Bolesłąw Ołomucki, Beniamin Pacanowski, Karol Piasecki, Izak Rajzman, Judyta Sobel, Dorota Szenfeld, Estelle Thomas i Zygmunt Waldman - „Mosty” 1948, nr 7, s. 7. Więcej „Opinia” 1949, nr 50, s. 23.

59 „Mosty” 1947, nr 11, s. 4.

60 „Opinia” 1947, nr 11, s 9. 
Spółdzielnia miała służyć z jednej strony celom zarobkowym, z drugiej zaś edukacyjnym. W tym celu utworzono przy niej studio malarsko-rzeźbiarskie. Działalność Spółdzielni wpisywała się w nurt współzawodnictwa robotniczego w sposób nieco zaskakujący dla działalności artystycznej. Oto bowiem 22 listopada 1948 r., w ramach licznych akcji związanych z kongresem zjednoczeniowym PPR i PPS, na zebraniu „robotników spółdzielni plastyków Sztuka” postanowiono ,jednomyślnie w następujący sposób uczcić historyczną datę zjednoczenia polskiej klasy robotniczej: 1. wykonać plan pracy za czwarty kwartał do 8 grudnia, 2. wzmóc produkcję przy jednoczesnym podniesieniu jej jakości, 3. zmniejszyć koszty produkcji celem uprzystępnienia jej szerokim robotnikom" $"$.

Jednym z zadań powierzonych spółdzielni było wykonanie jednej z ekspozycji w bloku 4, w uruchamianym w połowie 1947 r. Muzeum w AuschwitzBirkenau ${ }^{62}$.

\section{Towarzystwo Kultury $\dot{Z}$ ydowskiej ${ }^{63}$}

Potrzeba powołania tego typu organizacji zrodziła się z wielu powodów. Konieczność rozwijania kultury żydowskiej stanowiła istotny punkt działania zarówno Komitetów Żydowskich, jak i pojedynczych partii i organizacji. Dla żydowskich działaczy, którzy swoją przyszłość chcieli widzieć w Polsce, istotne stało się takie ukształtowanie działalności kulturalnej wśród rozproszonego i zdziesiątkowanego jiszywu, aby z jednej strony spełniało oczekiwania władz komunistycznych, z drugiej - pozwalało na jego unowocześnienie i scalenie. Oczywiście pamiętać należy, że taki przekaz kierowany był do tej części społeczeństwa żydowskiego, dla której religijność stanowiła jedynie element obrzędowości, a spuścizna przedwojennej kultury żydowskiej stawała się folklorem. Ponieważ rozwijanie kultury w ramach Komitetów Żydowskich uznane zostało za niewystarczające, zrodził się pomysł powołania w tym celu specjalnej organizacji. Inicjatywę jej powołania wysunęła Żydowska Frakcja PPR, a jej cel został sprecyzowany w deklaracji: „Jako organizacyjny wyraz samo twórczości żydowskiej ludności w dziedzinie żydowskiej kultury, Żydowskie Towarzystwo Kultury kontynuuje narodowo-twórcze i socjalno-postępowe tradycje polskiego żydostwa, dążąc do wychowania kadr bojowników i twórców żydowskiej kultury masowej, narodowej w treści i socjalistycznej w formie". Dalej czytamy o potrzebie „zbliżenia się żydowskiej i polskiej kultury, jako warunku wychowania żydowskiej ludności na dobrych obywateli i szczerych patriotów nowego, demokratycznego państwa polskiego"64. Szczegółowe

\footnotetext{
61 „Mosty” 1948, nr 139, s. 4.

${ }^{62} \mathrm{http}: / /$ pl.auschwitz.org.pl

${ }^{63} \mathrm{~W}$ czasopismach pojawiała się też nazwa Centralne Żydowskie Towarzystwo Kultury i Sztuki.

${ }^{64}$ AŻIH, ŻTK, 369/6, s. 1.
} 
zadania, o dosyć jednoznacznym wydźwięku ideologicznym, tak definiował Hersz Smolar, ówczesny szef Wydziału Kultury i Propagandy CKŻP:

„1. Zorganizować we wszystkich miastach Polski, gdzie tylko jest żydowska społeczność, lokalne oddziały Towarzystwa Kultury i Sztuki, zmierzając do tego, by wszystkie bez wyjątku żydowskie instytucje kulturalne stały się kolektywnymi członkami Towarzystwa Kultury.

2. Zaopatrzyć żydowskie koła dramatyczne i chóry w niezbędny repertuar i wskazówki metodyczne.

3. Wysłać do wszystkich ośrodków żydowskich referentów na żydowskie ogólne tematy kulturalne.

4. Zorganizować jednolite żydowskie biblioteki we wszystkich żydowskich ośrodkach, wzbogacić te biblioteki o literaturę, połączyć się w tym celu z wszystkimi większymi osiedlami żydowskimi na świecie.

5. Przejąć pod zarząd Towarzystwa istniejące studia dramatyczne i plastyczne oraz zorganizować żydowskie studium choreograficzne.

6. Wypracować programy, wskazówki metodyczne i konspekty lekcyjne dla żydowskich uniwersytetów ludowych.

7. Przygotować na początek 1948 r. powszechny żydowski kongres kultury w Polsce, który przyjmie deklarację ideową"

Powołaniem do życia Towarzystwa zajęto się podczas odbywającej się 22 listopada 1947 r. w Łodzi, w lokalu Związku Literatów i Dziennikarzy Żydowskich, ogólnokrajowej narady działaczy kultury żydowskiej. Miejsce narady nie było przypadkowe, w sytuacji gdyż do czołowych działaczy kulturalnych po wojnie zaliczyć trzeba przede wszystkim ocalałych literatów i na nich spoczywał obowiązek odrodzenia słowa żydowskiego i ocalenie resztek spuścizny Żydów polskich. Główne zadania stojące przed Towarzystwem przedstawił w referacie otwierającym naradę Hersz Smolar. Podkreślił przede wszystkim możliwości, jakie daje demokratyczna Polska dla rozwoju żydostwa i jak ważne $\mathrm{w}$ tej sytuacji jest nawiązanie ścisłego kontaktu z wszelkimi przejawami życia kulturalnego w Polsce, m.in. poprzez przekład współczesnej literatury polskiej na język jidysz oraz głębsze poznanie historii polskiej. Za szkodliwą uważał kulturalną autarkię, apelując o współpracę przede wszystkim z działaczami żydostwa Związku Radzieckiego, ale i też z postępowym jiszywem palestyńskim. Wytyczne dla działaczy kultury, zgodne z polityką CKŻP, a jednocześnie $\mathrm{z}$ polityką rządu, przewidywały również chłodny i sceptyczny stosunek do Żydów w Stanach Zjednoczonych, jako dążących do rozłamu i przeżywających poważne przesilenie kulturalne. Wojewódzkie Komitety nie były już w stanie dłużej kontynuować pracy na polu kultury ze względu na nieodpowiednie formy organizacyjne i wzrastające potrzeby kulturalne żydostwa polskiego. Natomiast Towarzystwo, które miało stać się organizacją masową, powinno prowadzić systematyczną pracę wśród Żydów,

\footnotetext{
${ }^{65}$ AŻIH, CKŻP, Prezydium, 7, s. 165, projekt dołączony do protokołu.
} 
m.in. walcząc $\mathrm{z}$ analfabetyzmem i zwiększając liczbę czytelników książki żydowskiej oraz zbliżając „do źródeł kultury żydowskiej wszystkich tych Żydów, którzy stoją jeszcze $\mathrm{z}$ dala od nas" ${ }^{\text {"66. }}$. W praktyce miało się to odbywać m.in. poprzez werbowanie jak największej ilości członków, zarówno indywidualnych jak i kolektywnych.

Wyłoniony podczas zebrania Komitet Organizacyjny nasteppnego dnia ukonstytuował władze Towarzystwa. Przewodniczącym został E. Kaganowski, zastępcami Mendelson i Gurwicz, sekretarzem D. Sfard, skarbnikiem Sztrachman i członkami zarządu Szner i H. Smolar ${ }^{67}$.

Zamierzeniem ŻTK było narzucenie instytucjom i organizacjom żydowskim swojej wizji rozwoju kulturalnego, dyktowanego już wówczas przez przyjętą przez władze CKŻP linię polityczną. Na wspomnianym wcześniej otwarciu wystawy zborowej plastyków Żydów w Łodzi w styczniu 1948 r. pisarz, a jednocześnie przewodniczący Towarzystwa rysował przed zebranymi cel jego powstania, a więc: „rozwinąć szeroką działalność, by przyswoić kulturze żydowskiej to wszystko, co Żydzi stworzyli najlepszego w dziedzinie sztuki, muzyki i literatury; by na tych doskonałych wzorcach budować w demokratycznej Polsce Ludowej nową kulturę żydowską”. I dalej zapewniał, że „malarz żydowski otrzymał obecnie adres, pod którym może się zwrócić w każdej potrzebie. Adresem tym jest i pozostanie na przyszłość Centralne Żydowskie Towarzystwo Kultury i Sztuki”,68. Gwoli ścisłości wspomnieć można przy tej okazji, że łódzkim adresem Towarzystwa była kamienica przy ul. Narutowicza 32, mieszkanie 15 - zbieżność z siedzibą Związku Żydowskich Literatów i Dziennikarzy nieprzypadkowa.

Pierwsze plenarne posiedzenie Zarządu Głównego ŻTK odbyło się w Łodzi w dniach 15 i 16 maja 1948 r. Sprawozdanie z działalności Towarzystwa przedstawił jego przewodniczący, E. Kaganowski, z kolei sekretarz generalny D. Sfard złożył sprawozdanie $\mathrm{z}$ aktywności oddziałów w ośrodkach żydowskich w Polsce. Szczegółowo natomiast zajęto się akcją Miesiąca Szkoły i Kultury Żydowskiej, zaplanowaną między 15 maja a 15 czerwca tegoż roku ${ }^{69}$. Podobny przebieg miało kolejne spotkanie plenarne w październiku 1948 r., Referat sprawozdawczy był już wygłoszony przez D. Sfarda, bo przewodniczący ŻTK E. Kaganowski opuścił Polskę wykorzystując pobyt na Konferencji Kultury Jidysz w Paryżu ${ }^{70}$. Członkowie Zarządu przyznali, że nie osiągnięto wszystkich

${ }^{66}$ Ogólnokrajowa narada działaczy Kultury żydowskiej w Lodzi, „Mosty” 1947, nr 80, s. 4.

${ }^{67}$ Ibidem.

68 „Mosty” 1948, nr 7, s. 7.

69 "Mosty" 1948, 22 V, s. 8.

70 M. Ruta, op.cit., s. 251. Razem z Kaganowskim pozostali wówczas zagranicą I. Aszendorf, Wogler i A. Zak. 
celów i postanowiono zwiększyć aktywność wśród ludności żydowskiej oraz wziąć czynny udział w miesiącu przyjaźni polsko-radzieckiej ${ }^{71}$.

19 października 1948 r. odbyła się z inicjatywy ŻTK bardzo znacząca konferencja poświęcona ortografii oraz terminologii naukowo-technicznej języka jidysz. Referaty wygłosili dr Rauchwerger i Ferdman, zaś w dyskusji wzięli udział przedstawiciele szkolnictwa, literaci, działacze ŻTK. Wszyscy podkreślali potrzebę położenia kresu chaosowi panującemu w prasie, książkach i wydawnictwach. Podczas konferencji wybrano komisję która miała zając się opracowaniem projektów ujednolicających zasady języka jidysz ${ }^{72}$.

Na początku marca 1949 r. ŻTK utworzyło w swojej siedzibie (a więc przy ul. Narutowicza $32 \mathrm{~m} \mathrm{15)} \mathrm{Sekcji} \mathrm{Plastyki,} \mathrm{do} \mathrm{której} \mathrm{zaproszono} \mathrm{plastyków-}$ Żydów. Do Towarzystwa należała też orkiestra, która akompaniuje pianistce Klimaszewskiej podczas koncertu szopenowskiego w Łódzkim Teatrze Żydowskim w 28 marca $1948 \mathrm{r}^{73}$ Próby opanowania i wpłynięcia na kształt żydowskiego życia kulturalnego najlepiej widać w podjętych przez ŻTK akcjach „wieczorów piątkowych". Zamiast tradycyjnej kolacji szabasowej organizowano wieczory poświęcone np. miesiącowi pogłębienia przyjaźni polsko-radzieckiej przy udziale żydowskich aktorów i literatów, (9 października 1949 r. w salach teatru żydowskiego), czy też spotkaniu z dramaturgiem z Francji dr. Chaimem Słowesem, któremu towarzyszyli muzycy żydowscy z Ameryki - Sylwia i Nachum Szmarow (4 listopada 1949 r. $)^{74}$.

Od połowy 1949 r. ŻTK przygotowywało się do Zjazdu Kultury Żydowskiej we Wrocławiu, organizując w tym celu akademie, wyznaczając sobie zadania w postaci wzmożonej akcji werbunkowej, zwiększenia członków chóru, walki $\mathrm{z}$ analfabetyzmem, zwiększenia abonentów prasy żydowskiej ${ }^{75}$.

\section{Teatr $\dot{Z}$ ydowski}

Oceniając osiagnięcia kulturalne jisziwu polskiego w pierwszych latach po wojnie przede wszystkim należy podkreślić ogromne znaczenie teatru żydowskiego. Podobnie jak w wielu innych dziedzinach teatr odradzał się przy aktywności wielu osób, nie zawsze zgodnych co do koncepcji dalszego rozwoju. Teatr dosięgły te same kłopoty, co i pozostałe organizacje, a więc śmierć wielu artystów sceny, ubóstwo tych, którym udało się przeżyć oraz niepewność co do dalszego losu w Polsce, skutkujące często decyzją o emigracji. Kolejnym wspólnym elementem było miejsce odradzania się teatru i wykuwania nowych koncepcji - najliczniej zamieszkałe wówczas przez Żydów miasto Łódź.

71 „Mosty” 1948, nr 121, s. 4.

72 „Opinia” 1948, nr 45, s. 10.

73 "Mosty" 1949, nr 28, s. 8; nr 39, s. 3.

74 „Mosty-Nasze Słowo”, 1949, nr 40, s. 5; nr 45, s. 9. Co prawda 9 października była niedziela, ale trudno stwierdzić, czy jest to pomyłka w dacie podana w „Mostach” czy też „piątkowe wieczory" urządzano w dowolne dni tygodnia.

75 „Mosty-Nasze Słowo” 1949, nr 33, s. 5. 
Myślę, że początek odradzania się scen żydowskich w Łodzi rozpoczął się wraz z pojawieniem się tu członków Związku Żydowskich Literatów, Dziennikarzy i Aktorów w Polsce. Aktorzy wyłączyli się z niego w maju 1946 r.

Jak wynika z notki zamieszczonej w pierwszym numerze „Opinii” z 10 lipca 1946 r., pierwsze dwa przedstawienia wystawione (zadowolić musimy się określeniem czasu: „ostatnio”) w Łodzi, to sztuka Szolem Alejchema Krwawy Żart zaprezentowana przez „Pierwszy Żydowski Teatr w Polsce” kierowany przez Z. Natana oraz program Jak uzyskać minien teatru rewiowego „Syraim” pod kierownictwem literackim M. Nudelmana. Recenzent chwalił dobrą grę Kalesznikowa w sztuce Alejchema oraz wytknął brak smaku w części tekstów rewiowych, ale mimo wszystko uznał przedstawienia za dobry początek odradzania się teatru żydowskiego, zwłaszcza w sytuacji śmierci $90 \%$ aktorów żydowskich $^{76}$.

Na poważnie za organizację łódzkiego teatru żydowskiego zabrał się Związek Artystów Scen Żydowskich w Polsce. W czasie odbywającego się w Łodzi w siedzibie Związku Literatów i Dziennikarzy Żydowskich przy ul. Narutowicza 32 w dniach 16-17 lipca 1946 r. zjazdu Związek zaapelował o zainteresowanie się sceną żydowską powołując do jej odtworzenia Radę Teatralną. W czasie zjazdu postanowiono utworzyć dwa zespoły teatralne pod patronatem ZASŻ, w Łodzi i Wrocławiu ${ }^{77}$. Łódzki teatr działał jako spółdzielnia przy ZASŻ, a na jego czele stał aktor - Mojżesz Lipman. Siedzibą teatru stał się budynek dawnego kina „Czary” przy ul. Jaracza 2, choć nie spełniał on podstawowych wymogów teatralnych, ani wymogów bezpieczeństwa. Premierowym przedstawieniem była Sonata Kreutzerowska Jakuba Gordina w reżyserii M. Lipmana wystawiona 3 sierpnia 1946 r., choć dopiero 24 sierpnia ZASŻ wystapił do Ministerstwa Kultury i Sztuki z prośbą o zgodę na prowadzenie teatru żydowskiego w Łodzi. Zgodę taką otrzymano, zatwierdzając jednocześnie M. Lipmana na kierownika artystycznego teatru, a M. Zaka - na administracyjnego ${ }^{78}$. Pierwszy rok działalności zakończono inscenizacją sztuki J. Gordina Bóg, czlowiek, szatan. W całym roku, mimo dosyć trudnych warunków lokalowych, kolektyw artystów, jak wówczas określano zespół aktorski, wystawił 12 premier. Obok wspomnianych przedstawień Gorodina rozpoczynających i kończących pierwszy rok pracy, teatr wystawił Wegierska karczmę Prizameta, Towje mleczarza, Poszukiwaczy złota i Wielka wygrana Szolem Alejchema, Mirete Efros i Sierotke Chasie J. Gorodina, Herszete Ostropoler Zonszajna, Dybuka Anskiego, Ojca Strinberga, oraz Czarodziejke Goldfadena ${ }^{79}$. Od momentu powstania teatru do końca 1946 r. wystawiono łącznie 74 przedsta-

76 „Opinia” 1946, nr 1, s. 10.

${ }^{77}$ M. Leyko, Ida Kamińska i Łódzki Teatr Żydowski, [w:] Łódzkie sceny żydowskie, pod red. M. Leyko, Łódź 2000, s. 157.

${ }^{78}$ APŁ, ZMŁ, 130, s. 9.

${ }^{79}$ M. Leyko, op.cit., s. 157. 
wienia, natomiast w całym 1947 r. - 113. Z zachowanych zestawień statystycznych wynika, że w 1947 r. przedstawienia oglądało 28133 widzów, czyli średnio 223 widzów na każdy spektakl ${ }^{80}$. Jak słusznie zauważył M. Melman jest to widownia obejmująca praktycznie 30-35\% ludności żydowskiej ${ }^{81}$.

Prawdopodobnie efemeryczną inicjatywę stworzenia w Łodzi Żydowskiego Teatru Kameralnego podjął się na początku 1947 r. autor i kompozytor S. Prizamet. Pierwszy program, zbiegający się z 70-leciem teatru żydowskiego w Polsce, poświęcony miał zostać ojcu teatru żydowskiego Abrahamowi Goldfadenowi. Brak jest jednak dalszych informacji o tej inicjatywie ${ }^{82}$.

Podsumowując pierwszy rok pracy teatru recenzent „Mostów” zwrócił uwagę na wysoki poziom gry aktorek w osobach: Eni Liton, Natalii Lipman, Keti Efron, Chany Białkowicz i Chany Kowalskiej. Spośród aktorów wyróżniali się: Mojżesz Lipman, Dawid Lederman, Ajzyk Rotman, Meir Melman, Natan Wolfowicz i Samuel Goldsztajn ${ }^{83}$. Oceniając dorobek teatru recenzent sygnalizował, że nie zawsze spotykał się z przychylnością krytyków: „Jakkolwiek można by wysnuć zastrzeżenia $\mathrm{w}$ stosunku do tych przedstawień, należy jedno stwierdzić, iż kolektyw artystów z kierownikiem artystycznym M. Lipmanem na czele dołożył wszelkich starań, by wkroczyć na drogę poważnego teatru"84. Inni recenzenci nie byli tak wyrozumiali dla Lipmana i wystawianych przez niego sztuk, podkreślając kultywowanie tradycyjnej przedwojennej miernoty teatralnej. Krytykowano też dobór repertuaru dramatycznego, opartego przede wszystkim na sprawdzonych przedwojennych sztukach ${ }^{85}$. Sytuacja zdecydowanie miała ulec poprawie od momentu objęcia dyrekcji artystycznej teatru przez wybitną aktorkę żydowską Idę Kamińską.

Kamińska powróciła do Polski ze Związku Radzieckiego w grudniu 1946 r. Pod koniec stycznia 1947 r. w siedzibie Związku Literatów i Dziennikarzy Żydowskich w Łodzi zostało wydane przyjęcie powitalne na cześć Idy Kamińskiej i jej męża Mariana (Meira) Melmana. Przemówienie powitalne wygłosili m.in. Michał Mirski, poeta Efraim Kaganowski, Mojżesz Lipman. Sama artystka wzruszona dziękowała mówcom „przyrzekając nadal poświęcić wszystkie siły swe i możliwości twórczej pracy na scenie teatru żydowskiego" ${ }^{" 86}$. Na powitanie para artystów przygotowała dwa „reprezentacyjne” wieczory w sali Teatru Żydowskiego przy ul. Jaracza 2, gromadząc tłumy widzów. W przedstawieniach wykorzystano fragmenty utworów Bialika, Pereca, Anskiego i Asza. Nie zabrakło też utworów o tematyce aktualnej - pokazano montaż utworów Binema

${ }^{80}$ L. Olejnik, Z dziejów teatru żydowskiego w Lodzi po II wojnie światowej, [w:] :] Lódzkie sceny żydowskie, pod red. M. Leyko, Łódź 2000, s. 147.

81 „Mosty” 1948, nr 107, s. 4.

82 „Opinia” 1947, nr 10, s. 20

${ }^{83}$ T. Jonasowicz, Rok pracy Łódzkiego Teatru Żydowskiego, „Mosty” 1947, nr 46, s. 7.

${ }^{84}$ Ibidem.

${ }^{85}$ Więcej por. M. Leyko, op.cit., s. 159.

${ }^{86}$ „Mosty” 1947, nr 9, s. 4. 
Hellera, Chaima Gradego i Icka Fefera pt. W getcie warszawskim przed Powstaniem oraz fragmenty ze sztuki Ghettograd Halkina ${ }^{87}$.

Już w następnym miesiącu Kamińska wraz $\mathrm{z}$ mężem wzięła udział w konferencji w Centralnym Komitecie Żydów Polskich w Warszawie poświęconej zagadnieniom teatru żydowskiego. Przedstawiciele władz CKŻP w osobach A. Bermana i $\mathrm{H}$. Smolara postawily przed teatrem żydowskim jednoznaczne zadania: wysoki poziom, reprezentacyjny charakter oraz dobór repertuaru, który „winien iść z nurtem życia i cechować go musi dynamika społeczno-narodowa" ${ }^{" 88}$. M. Lipman próbował zwrócić uwage na trudności, $\mathrm{z}$ jakimi borykają się organizatorzy teatru żydowskiego $\mathrm{w}$ Polsce i $\mathrm{w}$ jakiś sposób wytłumaczyć istniejącą sytuację za którą czuł się pewnie odpowiedzialny. Artyści woleli grać w sztukach, w których występowali już wielokrotnie, zwłaszcza wobec braku kostiumów i rekwizytów. Zupełnie inaczej przedstawiła swoją wizję teatru Ida Kamińska. Po katastrofie wojny nowy Teatr Żydowski stać się powinien „ogniwem i kitem zespalającym rozsypane po kraju resztki narodu, a jednocześnie winien być pomostem między krajem a środowiskiem żydostwa polskiego na całym świecie" ${ }^{\text {"9 }}$. Kamińska widziała potrzebę ustabilizowania teatru, po „przymusowej dorywczości 1946 r.”, zwłaszcza że nowe warunki społeczno-polityczne w Polsce współczesnej są czynnikiem sprzyjającym rozwojowi teatru. Nowością dla teatru było niewątpliwie jego oparcie zarówno w instytucjach rządowych, jak i pomocy CKŻP - instytucji stanowiącej wówczas, jak widziała to nie tylko Kamińska, urzeczywistnienie postulatu autonomii kulturalnej. To miał być koronny argument dla tych, którzy uważali, że centrum teatru żydowskiego Europy Środkowej i Zachodniej powinien być kraj o większej liczbie Żydów, na przykład Francja (Paryż). W swojej koncepcji Kamińska opowiadała się za utworzeniem jednego teatru $\mathrm{z}$ dwiema filiami. Zdawała sobie co prawda sprawę, że ,gdyby ludność żydowska była skoncentrowana w jednym mieście lub okolicy, wystarczyłby jeden teatr. Rozmieszczenie jednak ludności żydowskiej w Polsce, a więc w Łodzi, dla której peryferię wyjazdową stanowi Warszawa, oraz Dolny Śląsk, ze swoimi licznymi miejscowościami, gdzie nawet tysiącosobowe środowiska domagają się odwiedzenia teatru, przesądza kwestię gdyż nie można pozostawić ani Łodzi ani Śląska bez teatru żydowskiego". Takie rozwiązanie według niej ,decyduje też o charakterze tego teatru, który musi być objazdowym po części. Mamy obecnie ok. 40 aktorów żydowskich. Za mało na dwa teatry, za dużo na jeden. Najlepiej jest więc zorganizować jeden teatr z dwiema filiami w Łodzi i Dolnym Śląsku. (...) Charakter danego zespołu i jego repertuar zależy od jednolitego planowania, gdyż wtedy daje się stworzyć jeden zespół o obliczu ściśle dramatycznym, drugi

87 „Opinia” 1947, nr 11, s. 9.

88 "Mosty” 1947, nr 4 (36), s. 4.

89 AŻIH, 368/54, s. 319 (Zadania Teatru Żydowskiego i jego formy organizacyjne $w$ nowej Polsce - projekt przedstawiony przez I. Kamińską i M. Melmana, styczeń 1947) 
o charakterze rozrywkowym", Repertuar natomiast powinien przede wszystkim uwiecznić dramat Żydów w czasie wojny, a w dalszej kolejności podkreślać niezniszczalność narodu żydowskiego, jego postępowość i humanitaryzm. Wystawiane powinny być najlepsze sztuki ostatnich pięćdziesięciu lat (Hałkin, Goldfaden, Hirszbajn, Alter Kacyneze, Perec). Instytucją zwierzchnią dla teatru żydowskiego w Polsce, istotną przede wszystkim ze względu na zapewnianie pomocy materialnej, był CKŻP. Z jego też inicjatywy powołano Radę Teatralną, w skład której wchodzili członkowie prezydium Komisji, przedstawiciele Związku Artystów Żydowskich i Związku Literatów i Dziennikarzu Żydowskich, Jointu, Towarzystwa Krzewienia Kultury i Sztuki i WKŻ.

Wyraźnie widać więc, że małżeństwo pragnęło grać w sprawach teatru żydowskiego w Polsce pierwsze skrzypce, mimo że kierownikiem artystycznym teatru $\mathrm{w}$ Łodzi $\mathrm{w}$ dalszym ciagu pozostawał M. Lipman. Prawdopodobnie pożegnał się on $\mathrm{z}$ teatrem łódzkim po gościnnych występach w Paryżu, w każdym razie nazwisko aktorskiego małżeństwa Lipman nie pojawia się już w obsadzie przedstawień teatralnych. Opuszczone po Lipmanach mieszkanie przy ul. Jaracza 22 zajęła Kamińska. Oficjalnie kierownictwo artystyczne łódzkiego teatru objęła po powrocie $\mathrm{z}$ występów w Londynie, a pierwszym reżyserowanym przez nią przedstawieniem była komedia francuska Verneuilla i Beera Pani Adwokat. Premiera odbyła się 12 czerwca 1948 r. a spektakl, często grany w teatrach europejskich, stał się nowością w repertuarze łódzkiego teatru żydowskiego ${ }^{91}$. Plany na dalsze miesiące były bardzo ambitne - w połowie września $1948 \mathrm{r}$. teatr rozpoczął sezon premierą sztuki, o tematyce okupacyjnej, polskiej pisarki Anny Świerczyńskiej - Strzały na ulicy Dlugiej ${ }^{92}$. W październiku z kolei Ida Kamińska wystawiła dramat, w którym już przed wojną odnosiła sukcesy w Łodzi i w Polsce: Glikel Hameln. Żadam sprawiedliwości Maksa Baumana. Akcja sztuki dzieje się 250 lat temu w getcie w Hamburgu. Wdowa oskarża zabójcę swojego męża i żąda ukarania sprawcy. I mimo że jest biedną żydowską kobietą a sprawca „wytwornym kawalerem i chlubą Hamburga”, doprowadza do jego aresztowania. W rzeczywistości powojennej heroiczny wątek sztuki, żądanie sprawiedliwości i zadośćuczynienie „krzywdzie żydowskiej" nie stracił swej aktualności, a krytycy podkreślali, specjalną wymowę sztuki: „Glikl Hameln przełamuje milczenie, które tak bardzo cenią sobie wszelkiego rodzaju ciemiężcy"93. Łódzki WKŻ urządził nawet w listopadzie 1948 r. specjalne przedstawienie tej sztuki dla władz polskich. Przybyli na nie minister kultury i sztuki - Stefan Dybowski, prezydent miasta - Eugeniusz Stawiński, wicewojewoda - Szymanek, przedstawiciele partii, organizacji

\footnotetext{
${ }^{90}$ Ibidem, s. 320.

91 „Mosty” 1948, nr 69, s. 8.

92 "Mosty” 1948, nr 111, s. 8; H. Safrin, „Strzaly na ulicy Dlugiej”. Premiera $w$ Lódzkim Teatrze Żydowskim, „Mosty” 1948, nr 114.

93 „Mosty”, 1948, nr 126, s. 9; “Opinia” 1948, nr 45, s. 10 (zdjęcia z przedstawienia).
} 
społecznych, aktorzy, literaci, dziennikarze i nauczyciele. Witający gości sekretarz WKŻ Anatol Wertheim podkreślił wręcz, że oto po raz pierwszy aktor żydowski otrzymał możliwość zaprezentowania się społeczeństwu polskiemu, a istniejący do tej pory mur został przebity ,wraz z przejęciem władzy przez lud pracujący miast i wsi”. Minister Dybowski z kolei podkreślił przychylny stosunek rządu do rozwoju kultury żydowskiej w Polsce po wojennej katastrofie, aczkolwiek jego stwierdzenie, że „postępowa kultura żydowska w Polsce jest częścią składową postępowej kultury całego narodu polskiego" pokazały wyraźnie, jakie były oczekiwania nowej władzy ${ }^{94}$. Z pewnością nie był to dobry czas dla tradycyjnej kultury żydowskiej. Dla Idy Kamińskiej w dodatku przychylność władz istotna była zarówno ze względu na chęć utrzymania Teatru (subwencje!) jak i z przyczyn osobistych - na terenie Związku Radzieckiego wciąż przebywała jej córka, którą bezskutecznie starała się sprowadzić do Polski (wróciła dopiero w 1956 r.). Ukłonem w kierunku władz była premiera sztuki dramaturga rosyjskiego Aleksandra Ostrowskiego, Bez winy winni, której premiera odbyła się 11 grudnia 1948 r. Ida Kamińska grała w niej postać Kruczininy, matki bezgranicznie oddanej swojemu synowi ${ }^{95}$.

W sezonie 1948/1949 odbyła się jeszcze jedna premiera, tym razem rodzimego autora, Szymona Diamanta $W$ zimowa noc (19 lutego 1949 r. ), w reżyserii Idy Kamińskiej, scenografii malarza Aleksanda Bodena. Oryginalną muzykę skomponował Saul Berezowski. Sztuka ta ukazała się drukiem w wydawnictwie Jidisz Buch pod tytułem Żyd wśród rolników pod koniec 1948 r. i była przedmiotem licznych dyskusji jako pierwszy po wojnie oryginalny żydowski dramat ukazujący wydarzenia $\mathrm{z}$ okresu okupacji. Tematem sztuki są losy Żydów widziane są oczami polskiego chłopa na wsi w powiecie Jaworskim ${ }^{96}$.

W roku 1949 rozpoczęto zbiórkę funduszy na budowę teatru żydowskiego w Łodzi. Ta szczytna idea została rozpropagowana wśród wielu środowisk łódzkich, szczególny nacisk kładziono na środowiska robotnicze, co było wskazane $\mathrm{z}$ ideologicznego punktu widzenia. W ramach akcji zbierania funduszy organizowano wiece i tzw. zgromadzenia ludowe, którym towarzyszyły występy artystów z teatru żydowskiego. Środki na teatr, a właściwie Dom Kultury Żydowskiej, w której mieścić się miał teatr, zbierano również podczas Balu Purimowego 19 marca 1949 r., w salach Państwowej Wyższej Szkoły Teatralnej przy ul. Gdańskiej $32^{97}$. Z zamieszczanych w prasie żydowskiej w tym czasie sprawozdań ze zbierania środków na ten cel wynika, że większą hojnością cechowały się środowiska robotnicze a nie inteligenckie, co spotykało się z potępieniem członków Wojewódzkiego Komitetu Żydowskiego. Trudno jest niestety stwierdzić, na ile podkreślanie zaangażowania środowisk robotni-

\footnotetext{
94 „Mosty” 1948, nr 137, s. 7;

95 „Opinia” 1949, nr 48, s. 11

96 „Mosty” 1949, nr 20, s. 4. „Opinia” 1948, nr 47, s. 11.

97 „Mosty” 1949, nr 31, s. 8.
} 
czych nie stanowiło wygodnego elementu propagandy, wpisującego budynek teatru jako ,poważnego wkładu w dzieło budownictwa kultury socjalistycznej Nowej Polski" "98. Akcja spotkała się z oficjalnym poparciem władz wojewódzkich oraz polskich środowisk inteligenckich, co szło $\mathrm{w}$ zgodzie $\mathrm{z}$ oficjalną wówczas linią rządu popierającą odradzanie się żydowskiej kultury.

Budowa teatru żydowskiego szła $\mathrm{w}$ parze $\mathrm{z}$ zabiegami Idy Kamińskiej o upaństwowienie teatru żydowskiego. Miało to z jednej strony zabezpieczyć finansowo aktorów, z drugiej zaś - osadzić żydowską kulturę w oficjalnej przestrzeni publicznej. Dla ludności żydowskiej miało to wymiar symboliczny. Sama Ida Kamińska wspominała, że jej matka, wybitna aktora Ester Rachel Kamińska, ,pragnęła zawsze, by teatr był utrzymywany przez gminę, nie śmiała jednak nawet marzyć o teatrze państwowym"99.

Zabiegi o upaństwowienie teatru, jak osobista sytuacja Kamińskiej walczącej o zgodę na powrót do Polski ze Związku Radzieckiego córki z rodziną, zaważyły pewnie na repertuarze teatru. Sezon artystyczny w 1949 r. otwarty zostal premierą radzieckiej komedii Isajewa i Halicza Wzywa was Tajmyr, która, jak opisał to recenzent „pokazuje w zabawny sposób ludzi radzieckich zawsze gotowych do pomagania sobie, zwłaszcza w trudnym czasie budowy Kraju Rad" ${ }^{100}$. Do zespołu dołączyli wówczas Chewel Buzgan i Rywka Szyler, aktorzy znanych z polskich żydowskich teatrów przed wojną. Do Polski przyjechali z Argentyny, by tu podejmować starania o powrót ze Związku Radzieckiego córki i wnuczki ${ }^{101}$. Kolejne premiery zaplanowane na ten sezon miały wykazać zaangażowanie teatru żydowskiego $\mathrm{w}$ unowocześnienie repertuaru poprzez inscenizowanie, obok sztuk dramaturgów żydowskich, autorów radzieckich bądź sztuk mających podobać się władzy. Wystawiona miała zostać sztuka węgierskiego pisarza Szandora Gergelyego Mój syn o tematyce antyfaszystowskiej, inscenizacja widowiska osnutego na motywach pisarstwa Pereca w 35. rocznicę śmierci pisarza, nowe opracowanie sztuki Goldfadena Dziesiate przykazanie oraz dramat młodego pisarza izraelskiego J. Mossinossa W pustkowiach Nege$w u$. W salach nowo wybudowanego budynku przy ul. Więckowskiego planowano wystawić Optymistycznq tragedie Wsiewołoda Wiszniewskiego, W pewnym kraju Mikołaja Wirty, Rewizora Gogola i Meira Ezofowicza Elizy Orzeszkowej. Kamińskiej nie udało się zrealizować zaplanowanych wszystkich inscenizacji, jedynie - dramat Mój syn (premiera 19 listopada 1950 r.) i Wieczór Szolem Alejchemowski (premiera 4 marca 1950 r.). Wraz z upaństwowieniem w listopadzie 1949 r. teatru połączono łódzką scenę z teatrem dolnośląskim z siedzibą we Wrocławiu. Za takim rozwiązaniem przemawiać miał fakt, że na Dolnym Śląsku mieszkało więcej Żydów, choć podejrzewać należy, że w grę wchodziły także

\footnotetext{
${ }^{98}$ Ibidem.

${ }^{99}$ I. Kamińska, Moje życie, mój teatr, Warszawa 1995, s. 217.

100 „Mosty” 1949, nr 28, s. 4.

${ }^{101}$ I. Kamińska, op.cit., s. 207.
} 
konflikty wewnątrz zespołów i rywalizacja o pozycję teatrów ${ }^{102}$. Kolejne premiery w sezonie 1949/1950 realizowane już były przez aktorów związanych z wrocławskim teatrem żydowskim: 9 kwietnia 1950 r. Sen o Goldfadenie w reżyserii Jakuba Rothbauma, 10 czerwca - Przyjaciele Andrieja Uspieńskiego w reżyserii Izaaka Grundberga-Turkowa i Sender Blank Sz. Alejchema wystawione przez Jakuba Rothbauma. Sytuacja ta nie trwała długo, bo już w maju 1950 r. siedzibą teatru żydowskiego ponownie została Łódź. Z racji malejącej liczby Żydów w Łodzi i częstych występów gościnnych z nowego budynku zaczął korzystać polski Teatr Nowy kierowany przez Kazimierza Dejmka i Janusza Warmińskiego. Ida Kamińska, nie ustawała w zabiegach przeniesienia teatru do Warszawy, co jak sama przyznawała, było „naturalną koleją rzeczy”"103. Koniec łódzkiego etapu polskiego teatru żydowskiego nastąpił w $1954 \mathrm{r}$. Te kilka łódzkich lat teatru żydowskiego było z pewnością bogatym okresem w jego historii. Zespół, zebrany po wojennej zawierusze, musiał stawić czoło z jednej strony ciężarowi wojennych wspomnień, z drugiej - oczekiwaniom nowej władzy. Niewątpliwie osoba wybitnej aktorki Idy Kamińskiej miała zdecydowany wpływ na oblicze teatru. $Z$ kolei panująca w ciagu tych kilku lat powojennej autonomii Żydów i przekonaniu, że możliwe będzie w jej ramach prowadzenie bogatego życia kulturalnego i renesans narodowy, zaowocowała bezprecedensową akcją powszechnej zbiórki funduszy na budynek teatru żydowskiego, obecną siedzibę Teatru Nowego w Łodzi.

\section{Repertuar rozrywkowy}

Pragnienie Kamińskiej stworzenia w Łodzi teatru dramatycznego nie zawsze szło $\mathrm{w}$ parze $\mathrm{z}$ oczekiwaniami publiczności. Trudno zresztą winić publiczność, która w dużej mierze nie była wykształcona i w dodatku, co podkreślane jest w wielu wspomnieniach, w lekkiej rozrywce znajdywała zapomnienie czasu wojny. Stąd ogromna popularność w Łodzi przedwojennych komików Dżigana i Szumachera, którzy powrócili do Łodzi ze Związku Radzieckiego w sierpniu 1947 r. i wkrótce wystapili z pierwszym przedstawieniem w sali Teatru Wojska Polskiego, witani oficjalnie przez A. Wertheima w imieniu WKŻ, D. Sfarda w imieniu Rady Teatralnej przy CKŻP oraz w imieniu Związku Artystów Żydowskich - M. Melmana ${ }^{104}$. Na pierwsze występy powitalne w łódzkim teatrze Wojska Polskiego przybyły thumy. Przedstawienie zawierało zarówno scenki przedwojenne (Pożar w Karsylewce) Sz. Alejchema i A frejlechs Bialika. Najgoręcej oklaskiwano scenki o wydźwięku aktualnym, m.in. Kłopoty z nazwiskiem czy Telefon.

\footnotetext{
${ }^{102}$ Ibidem, s. 210-211.

${ }^{103}$ Ibidem, s. 215.

104 „Opinia” 1947, nr 23/24, s. 19.
} 
W styczniu 1948 r. ukazał się anons o objęciu przez Dżigana i Szumachera kierownictwa artystycznego Teatru Żydowskiego w Lodzi ${ }^{105}$, lecz brak jest dalszych informacji o pełnieniu przez nich tych funkcji. Jest to raczej sygnał o wciąż jeszcze nie ustabilizowanej sytuacji teatru żydowskiego oraz istniejących w tym środowisku tarciach i walkach o władzę.

$\mathrm{Na}$ początek 1948 r. przygotowana została przez obu komików rewia Co dalej szary człowieku. W spektakl włączono zarówno sceny i miniatury sprzed wojny, oparte na szablonowych trikach Dżigana i Szumachera. Pojawiły się też akcenty współczesne, w postaci wykonanych przez pieśniarkę Rozę Rajską utworów J. Janasowicza $\mathrm{Na}$ szlakach rosyjskich i Tel Awiw oraz tańca Sylwii Swan Motywy getta. Recenzujący rewię Horacy Safrin wytknął jej zbytnią powierzchowność oraz brak odniesienia do przyszłości, ukazania życia „owianego nadzieją lepszego jutra”. Krytyka ta najwyraźniej przebiegała wzdłuż ideologicznej linii podziału i sposobu postrzegania rzeczywistości. Niemniej wywołała ostry sprzeciw komików, którzy zaatakowali recenzenta z desek sceny przy kolejnym przedstawieniu rewii ${ }^{106}$. Publiczna dyskusja zakończyła się polubownie - po kolejnej premierze spłynęły na komików słowa pochwały za odpowiedni dobór tekstów do rewii Bałabatisz un demokratisz. Premiera tego przedstawienia odbyła się 26 września 1948 r. Do ulubionych przez widzów fragmentów należał ponoć skecz $\mathrm{z}$ wykorzystaniem kukieł osób znanych $\mathrm{z}$ aktualnego życia politycznego, m.in. Mołotowa, Trumana i Marshalla. Rewia cieszyła się ogromną popularnością. W styczniu $1948 \mathrm{r}$. z dumą donoszono o jej 50. przedstawieniu ${ }^{107}$. Przedstawień było o wiele więcej, skoro jeszcze w październiku 1948 r. ukazała się w prasie nader życzliwa rewii recenzja ${ }^{108}$. Popularność komików wśród mieszkańców Łodzi nie oznaczała jednak uznania w oczach bardziej wyrobionej artystycznie publiczności. Zdawano sobie jednak sprawę z „wielkich trudności repertuarowych, jakie po wojnie zaistniały we wszelkich dziedzinach żydowskich sztuk odtwórczych” oraz że „szczególnie osierocona została dziedzina satyry i humoru, która nie posiada wśród literatów ani jednego reprezentanta. W tych warunkach występy Dżigana i Szumachera (którzy są autorami większej części granych przez siebie tekstów) nabierają specjalnego znaczenia”, mimo że ,ich trywialne numery, jakkolwiek bawią publiczność, pozostawiają osad zażenowania" ${ }^{209}$.

W styczniu 1949 r. komicy za miejsce występowania obrali Teatr Wojska Polskiego, gdzie występowali wraz ze słynną pieśniarką Dorą Kalinówną ${ }^{110}$.

W sumie w czasie powojennego pobytu w Łodzi wystawili 3 rewie: $N u$, $u n$ wos wajter, Zingendik un tancedik oraz Demokratisz un batebatisz.

\footnotetext{
105 „Opinia” 1948, nr 28, 25 I, s. 9.

106 „Mosty” 1948, nr 124, s. 6-7; „Mosty” 1948, nr 133, s 4.

107 „Mosty” 1949, nr 10, s. 8.

108 „Opinia” 1948, nr 44, s. 11.

109 "Mosty” - Nasze Słowo”, 1949, s. 3.

110 „Opinia”1948, nr 48, s. 11.
} 


\section{Film żydowski}

Na początku 1945 r. powrócili z ZSRR do Polski słynni przedwojenni producenci filmowi bracia Saul i Izak Goskind. W tym czasie dotarła też do Polski wraz z wojskami radzieckimi kierowana przez Aleksandra Forda Czołówka Filmowa I Dywizji Piechoty LWP, osiedlając się w Łodzi. W lipcu 1945 r. Czołówka Filmowa została przekształcona w przedsiębiorstwo państwowe Film Polski, a zbudowane dla niego studio przy ul. Łąkowej dało początek Łodzi filmowej. Początkowo bracia Goskindowie liczyli na współpracę z Fordem chcąc w ramach Filmu Polskiego kręcić filmy żydowskie. Jak po latach wspominał Saul Goskind propozycję tę Aleksander Ford skomentował: „Po co ci filmy żydowskie? Przecież Żydów nie ma. Urządzę cię jako kierownika produkcji w Filmie Polskim"111. O planowanej współpracy z Filmem Polskim świadczy zapowiedź pierwszego dźwiękowego filmu o życiu Żydów w Polsce, od czasów Kazimierza Wielkiego po teraźniejszość pt. Stuchaj Izraelu. Autorami wyczerpującego scenariusza byli literaci Bernard Mark, Szymon Spund, Stanisław (Saul) Goskind i Mojżesz Grosman. Film miała poprzedzić kronika filmowa obrazująca obecne aktualia żydowskie. Brak jest jednak dalszych informacji o realizacji tego filmu ${ }^{112}$. Natomiast Goskind rozpoczął pracę niezależnie od Filmu Polskiego w oparciu o środki z Joint oraz za zgodą Centralnego Komitetu Żydów w Polsce założył spółdzielnię produkującą filmy o tematyce żydowskiej i w języku jidysz. Spółdzielnia nosiła nazwę „Kinor” - skrót od nazwy KinoOrganizacja. Oficjalną siedzibą firmy była Warszawa, niemniej działalność i ekipa produkcyjna związana była z Łodzią. Producentem był Saul Goskind, pomagał mu brat Izak, pracujący jednocześnie przy tworzonym przez siebie archiwum filmowym. Zdjęcia realizowali najczęściej Albert i Władysław Forbert, muzykę komponował aktywny wówczas w Łodzi kompozytor Saul Berezowski. Reżyserem i scenarzystą był Natan Gross. Potrzebną do pracy ekipę w postaci elektryków, pomocników, montażystów dostarczał Film Polski, który również dostarczał sprzęt i surowiec. Sfilmowany materiał był opracowany w laboratoriach Filmu Polskiego, a całość produkcji finansowany był przez Joint za pośrednictwem CKŻP ${ }^{113}$. Zamiarem Saula Goskinda było filmowanie bieżących wydarzeń z życia Żydów w Polsce w formie co miesięcznej kroniki. A ponieważ wiele z tych wydarzeń miała miejsce w Łodzi, stąd też Łódź została na tych taśmach utrwalona. Powojenna Łódź stała się również tłem innych filmów wyprodukowanych przez „Kinor”. Odnajdziemy ją w cyklicznie powstających kronikach filmowych dokumentujących m.in. otwarcie teatru żydowskiego w sierpniu 1946 r., wystawy sztuki malarskiej, życie w kibucach, repatriacja ze Związku Radzieckiego czy też film poświęcony Towarzystwu Opieki Zdrowotnej (TOZ), której centrala znajdowała się w Łodzi. Wiele z tych

\footnotetext{
${ }^{111}$ N. Gross, Film żydowski w Polsce, Kraków 2002, s. 118.

112 „Opinia” 1946, nr 2, s. 10.

${ }^{113}$ N. Gross, op.cit., s. 120.
} 
materiałów weszło potem w skład długometrażowego filmu dokumentalnego Mir, lebngeblibene (My, którzy przeżyliśmy), produkowanego od września 1946 r. do kwietnia 1948 r. Premiera filmu miała miejsce 4 kwietnia 1948 r. w kinie Włókniarz w Łodzi ${ }^{114}$. Film został zrealizowany przez Saula Goskinda i Natana Grossa, autorem zdjęć był Jakub Goldberg, tekst narracji napisał wybitny nowelista żydowski Efraim Kaganowski, a muzykę skomponował Saul Berezowski. Film składa się z 10 części, każda rozpoczyna się osobnym tytułem, nadając całości formę albumu fotografii. Dla miłośników historii Łodzi film ten to prawdziwa kopalnia materiałów i zdjęć miasta tuż po wojnie. Kamera pokazuje ludzi poszukujących krewnych i wracających ze Związku Radzieckiego, znajdujących miejsca do zamieszkania w Domu Repatrianta w Lodzi przy ul. Jakuba $16^{115}$. Jedna z części filmu poświęcona jest opiece nad dziećmi, m.in. pokazany jest jeden dzień w domu dziecka w Helenówku pod Łodzią. Filmowane są występy dzieci oraz wizyta w domu dziecka żydowskich artystów: śpiewaczki Fani Rubina oraz tancerzy - Judyty Berg i Feliksa Fibicha. Dzieci śpiewają m.in. po polsku Przqśniczkę. Następna część odsłania kulisy życia w kibucach, również łódzkich, w których młodzież żydowska przygotowywała się do wyjazdu do Izraela. Operatorzy docierają do kibuców Droru. Gordoni, Ichudu czy też Haszomer Hacair przy ul. Kilińskiego 49. Równie ważnym elementem odbudowy żydowskiego życia w Polsce i w Łodzi były spółdzielnie pracy. W filmie pokazane zostały zakłady krawieckie, szewskie, żydowskie piekarnie oraz spółdzielnia „Przyszłość”. W dokumencie pokazano również działalność Centralnej Żydowskiej Komisji Historycznej, m.in. osoby Kermisza i Blumentala, prace nad uporządkowaniem materiałów z okresu okupacji oraz część zbiorów w postaci szkiców zmarłego w getcie łódzkim artysty Maurycego Trębacza czy też wykonane przez Braunera w getcie lalki. Znaczący fragment filmu poświęcony jest odradzaniu się życia kulturalnego Żydów, ukazuje skupionych w Stowarzyszeniu Pisarzy i Dziennikarzy Żydowskich ludzi pióra: Leona Finkelsteina, Rachelę Auerbach, Mosze Grossmana, Wolfa Jasnego, Michała Mirskiego, Jeszajahu Szpigla oraz ukazującą się wówczas, przede wszystkim w Łodzi, prasę żydowską w języku polskim i jidysz. Kolejnym bohaterem filmu jest Paweł Willenberg, znany żydowski malarz, inicjator założenia spółdzielni Artystyczno-Malarskiej „Sztuka”, oraz dzieła skupionych w niej artystów: H. Hechtkopfa, Pacanowskiego czy Feingolda. Istotnym fragmentem filmu są fragmenty spektakli z łódzkiego teatru żydowskiego z występującymi tu Mojżeszem i Natalią Lipman (Tewje Mleczarz) czy też Idą Kamińską i Marianem Melmanem.

114 „Mosty” 1948, nr 39, s. 4. Film jest dostępny w internetowym archiwum S. Spielberga.

${ }^{115}$ Budynek ten odegrał też swoją znaczącą rolę w czasie wojny. To tutaj zlokalizowany był wielki zakład krawiecki w getcie łódzkim, w okresie zaś likwidacji getta - obóz dla osób pozostawionych do sprzątania terenu. 
W 1947 r. zrealizowany został dziesięciominutowy film przedstawiający dzień młodzieży w kibucu Gordonia w Łodzi, reżyserowany przez Natana Grossa. Z kolei Helenówek stał się miejscem akcji jedynego filmu fabularnego wyprodukowanego przez „Kinor” Unzere kinder (Nasze dzieci). Zamysł filmu, jak opisał po latach jego reżyser Natan Gross, powstał w chwili powrotu do Polski Dżigana i Szumachera. Chciano wykorzystać talent aktorski obu komików, a jednocześnie nie zapominać o sytuacji, w której znajdowali się Żydzi po Zagładzie. Stąd zamysł ulokowania akcji filmu w Domu dziecka, gdzie Dżigan i Szumacher, wystepując pod swoimi nazwiskami, przedstawiają dzieciom skecze, m.in. Pożar w Kasrylewce. Wizyta aktorów wywołuje u dzieci wspomnienia z czasu wojny, na opowieściach upływa cała noc. Ostatnia scena pokazująca dzieci odprowadzające aktorów do miasta ilustrowana jest pieśnią Nie mów nigdy, że w ostatniq drogę idziesz napisaną przez Binema Hellera do muzyki Saula Berezowskiego.

We wszystkich filmach produkowanych prze „Kinor” narracja prowadzona była oczywiście w języku jidysz. Problemem producentów była dystrybucja filmów. My, którzy przeżyliśmy wyświetlany był kilkakrotnie w Łodzi i Szczecinie, prawdopodobnie w Warszawie. Nieznany był jednak szerszej publiczności, o polskich widzach nie wspominając. Podobnie było z filmem Nasze dzieci, wyświetlonym tylko raz na zamkniętym pokazie. O tym, że produkowane przez „Kinor" filmy, mimo finansowego wsparcie Jointu i Centralnego Komitetu Żydów w Polsce nie cieszyły się praktycznie poparciem i akceptacją żydowskich instytucji społecznych i kulturalnych, przekonywał Natan Gross w artykule opublikowanym w „Naszym Słowie” w 1949 r. ${ }^{116}$ Wyraźne propagowanie idei syjonistycznych nie do końca zgadzało się z zamiarami władz CKŻP, starających się w owym czasie nie zachęcać do wyjazdów z Polski. Mając świadomość tej sytuacji, założyciele „Kinoru”, zakończyli działalność spółdzielni i wyjechali do Izraela, gdzie nadal wspólnie produkowali filmy w utworzonej wytwórni Kolon $^{117}$.

Kresem tej swoistej autonomii narodowej ludności żydowskiej w Polsce stała się postępująca stalinizacja kraju, na fali której w 1949 r. partie zostały zlikwidowane, wiele organizacji żydowskich, również o charakterze kulturalnym, zostało rozwiązanych bądź przyłączonych do polskich odpowiedników. CZ̈KP od połowy 1949 r. był już kontrolowany przez komunistów. Kresem jego działalności i symbolicznym końcem nadziei na ugruntowanie autonomii żydowskiej w Polsce było powstanie w październiku 1950 r. Towarzystwa Społeczno-Kulturalnego Żydów w Polsce, w wyniku połączenia Komitetu i Towarzystwa Kulturalnego Żydów. Profil ideologiczny tej organizacji nie pozostawiał miejsca na jakąkolwiek samodzielność narodową, dbając o rozwój życia żydowskiego w Polsce zgodnie $\mathrm{z}$ ideologicznymi wymogami realnego socjalizmu.

\footnotetext{
116 „Nasze Słowo” 1949, nr 9-10, s. 12.

${ }^{117}$ N. Gross, op. cit., s. 133.
} 